\title{
The 1986 Residential Occupant Survey
}

\author{
D. L. Ivey \\ P. K. Alley
}

April 1987

Prepared for the Bonneville Power Administration under a Related Services Agreement with the U.S. Department of Energy Contract DE-AC06-76RLO 1830

Pacific Northwest Laboratory Operated for the U.S. Department of Energy by Battelle Memorial Institute 


\title{
DISCLAIMER
}

This report was prepared as an account of work sponsored by an agency of the United States Government. Neither the United States Government nor any agency thereof, nor Battelle Memorial Institute, nor any of their employees, makes any warranty, expressed or implied, or assumes any legal liability or responsibility for the accuracy, completeness, or usefulness of any information, apparatus, product, or process disclosed, or represents that its use would not infringe privately owned rights. Reference herein to any specific commercial product, process, or service by trade name, trademark, manufacturer, or otherwise, does not necessarily constitute or imply its endorsement, recommendation, or favoring by the United States Government of any agency thereof, or Battelle Memorial Institute. The views and opinions of authors expressed herein do not necessarly state or reflect those of the United States Government or any agency thereof, or Battelle Memorial Institute.

\author{
PACIFIC NORTHWEST LABORATORY \\ operated by \\ BATTELLE MEMORIAL INSTITUTE \\ for the \\ UNITED STATES DEPARTMENT OF ENERGY \\ under Contract DE-AC06-76RLO 1830
}

Printed in the United States of America
Available from
National Technical Information Service
United States Department of Commerce
5285 Port Royal Road
Springfield, Virginia 22161
NTIS Price Codes
Microfiche A01
Printed Copy
Pages
$001-025$
$026-050$


THE 1986 RESIDENTIAL OCCUPANT SURVEY

D. L. Ivey

P. K. Alley

Aprit 1987

Prepared for the

Bonneville Power Administration under a Related Services Agreement with the U.S. Department of Energy Contract DE-AC06-76RLO 1830

Pacific Northwest Laboratory Richland, Washington 99352 


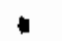

.

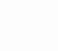

,

b

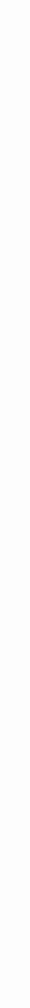


SUMMARY

In 1986, Pacific Northwest Laboratory developed the Residential Occupant Survey-Spring '86, which was implemented by Market Trends of Bellevue, Washington. The overall purpose of the study was to collect demographic, attitudinal, and behavioral data related to the use and conservation of electricity in dwellings participating in the Bonneville Power Administration's End-Use Load and Conservation Assessment Program (ELCAP).

Information was collected on the respondents' perceptions of the energy efficiency of their dwelling, temperature the dwelling was kept when people were at home and awake during the last heating season, which rooms, if any, were not heated during the last heating season, number of times the dwelling was unoccupied for at least one week, number of times pets were let out of the dwelling per day, attitudes toward energy use and conservation and several socio-demographic variables such as age, sex, and total household income.

The results of the data analyses showed age to be an important factor for reported indoor temperature and perceived energy efficiency of the dwelling. The results also showed that almost $60 \%$ of the ElCAP occupants do not heat one or more rooms during the heating season, and almost $45 \%$ of the ELCAP dwellings were unoccupied for at least one week during the reporting period. In terms of the reported allocation of household income for household energy expenses, the results showed that the reported dollar amount spent for the expenses remained relatively constant over income levels.

The information collected in the 86R0S will be useful to a number of studies both currentiy and in the future. For example, much of the data is currently being used to update the Fundamental Residential Characteristics data set for ELCAP residences. 
$\bullet$ 


\section{CONTENTS}

SUMMARY

1.0 INTRODUCTION $\ldots \ldots \ldots \ldots \ldots \ldots \ldots \ldots \ldots \ldots \ldots \ldots \ldots \ldots \ldots \ldots \ldots \ldots \ldots \ldots \ldots \ldots$

2.0 CONCLUSIONS AND RECOMMENDATIONS $\ldots \ldots \ldots \ldots \ldots \ldots \ldots \ldots \ldots \ldots \ldots \ldots \ldots \ldots$

3.0 SURVEY DESIGN AND IMPLEMENTATION $\ldots \ldots \ldots \ldots \ldots \ldots \ldots \ldots \ldots \ldots \ldots \ldots \ldots \ldots$

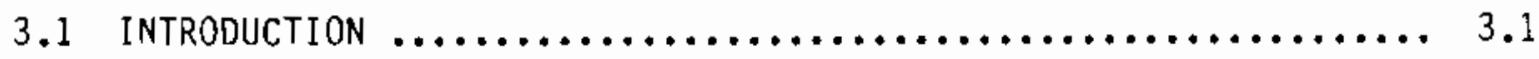

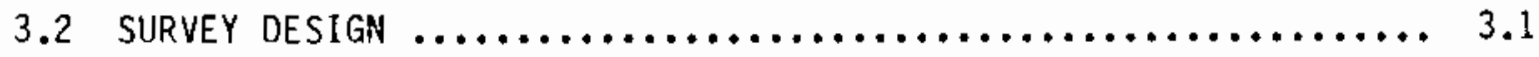

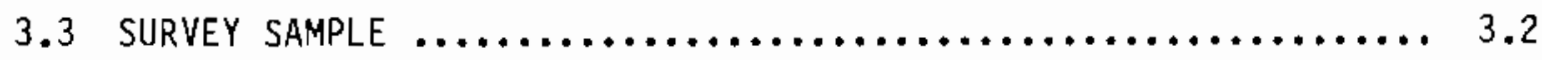

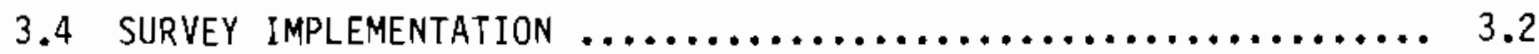

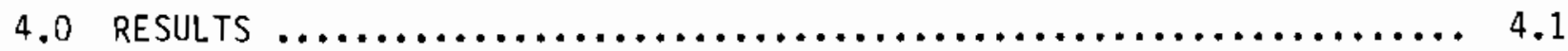

4.1 INTRODUCTION $\ldots \ldots \ldots \ldots \ldots \ldots \ldots \ldots \ldots \ldots \ldots \ldots \ldots \ldots \ldots \ldots \ldots \ldots \ldots \ldots$

4.2 SOCIO-DEMOGRAPHIC INFORMATION $\ldots \ldots \ldots \ldots \ldots \ldots \ldots \ldots \ldots \ldots \ldots \ldots . \ldots \ldots$

4.3 BEHAVIORAL INFORMATION $\ldots \ldots \ldots \ldots \ldots \ldots \ldots \ldots \ldots \ldots \ldots \ldots \ldots \ldots$

4.4 ATTITUDINAL INFORMATIDN $\ldots \ldots \ldots \ldots \ldots \ldots \ldots \ldots \ldots \ldots \ldots \ldots \ldots \ldots$

4.5 ALLOCATION OF TOTAL HOUSEHOLD INCOME $\ldots \ldots \ldots \ldots \ldots \ldots \ldots \ldots \ldots . . .17$

APPENDIX A--SURVEY QUESTIONNAIRE $\ldots \ldots \ldots \ldots \ldots \ldots \ldots \ldots \ldots \ldots \ldots \ldots \ldots \ldots \ldots$

APPENDIX B--SURVEY FREQUENCIES $\ldots \ldots \ldots \ldots \ldots \ldots \ldots \ldots \ldots \ldots \ldots \ldots \ldots \ldots \ldots \ldots$ 


\section{TABLES}

4.1 86R0S Socio-Demographic Information $\ldots \ldots \ldots \ldots \ldots \ldots \ldots \ldots \ldots \ldots . . .2$

4.2 Total Household Income by Age of the Residents $\ldots \ldots \ldots \ldots \ldots \ldots \ldots, 4.4$

4.3 Total Household Income by Education Level $\ldots \ldots \ldots \ldots \ldots \ldots \ldots . . . \ldots .4$

4.4 Temperature the Dwellings are Kept when the Household is Home and Awake by Age of the Residents $\ldots \ldots \ldots \ldots \ldots \ldots \ldots \ldots . . .64 .5$

4.5 Temperature the Dwellings are Kept When the Household is Home and Awake by Respondent's Attitude Toward the Statement "In the winter, I find it difficult to be comfortable when the temperature in my home is $68^{\circ} \mathrm{F}$ or less." $\ldots \ldots \ldots \ldots \ldots \ldots \ldots \ldots \ldots .6 .6$

4.6 Dwellings with Unheated Rooms $\ldots \ldots \ldots \ldots \ldots \ldots \ldots \ldots \ldots \ldots \ldots \ldots, 4.6$

4.7 Dwellings that were Unoccupied for at Least 0ne Week ............ 4.7

4.8 Number of Times a Day Pets are Let Out of the Heated Part of the Dwelling $. \ldots \ldots \ldots \ldots \ldots \ldots \ldots \ldots \ldots \ldots \ldots \ldots \ldots \ldots \ldots \ldots \ldots \ldots \ldots, 4.8$

4.9 Perceived Energy Efficiency of Occupants Home by Respondent's

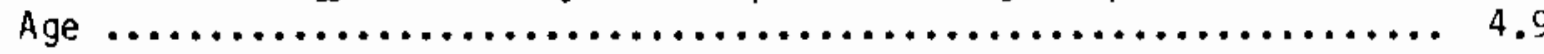

4.10 Perceived Energy Efficiency of Occupant's Home by

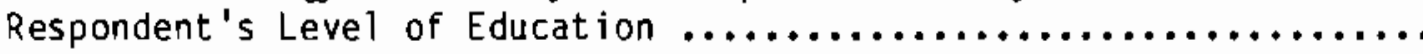

4.11 Perceived Energy Efficiency of Dwelling by Employment Status of 0 ccupants $\ldots \ldots \ldots \ldots \ldots \ldots \ldots \ldots \ldots \ldots \ldots \ldots \ldots \ldots \ldots \ldots \ldots, 4.10$

4.12 Perceived Energy Efficiency of Occupant's Home by Total Household Income

4.13 Perceived Energy Efficient of Occupant's Home by Temperature the Dwellings are Kept when the Household is Home and Awake ...... 4.11

4.14 Perceived Energy Efficiency of Occupant's Home by Amount of 1985 Total Household Income Allocated to Household Energy

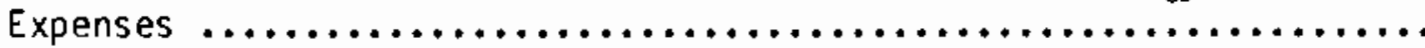

4.15 Perceived Energy Efficiency of Occupant's Home by Respondents Attitude Toward the Statement "It's hard for me to get around to making my home more energy efficient" $\ldots \ldots \ldots \ldots \ldots \ldots \ldots \ldots \ldots . . .12$

4.16 The 86ROS Oemographic Information by Respondents' Attitudes Toward the Statement "In the winter I find it difficult to be comfortable when the temperature in my home is $68^{\circ} \mathrm{F}$ or less" 
4.17 The 86R0S Demographic Information by Respondents' Attitudes Toward the Statement "Reducing the temperature of the water heater from $140^{\circ} \mathrm{F}$ to $120^{\circ} \mathrm{F}$ saves enough energy to make it worth doing

4.18 The 86R0S Demographic Information by Respondents' Attitudes Toward the Statement "The main reason to conserve energy is to save money"

4.19 The 86R0S Demographic Information by Respondents 'Attitudes Toward the Statement "During the winter, when no one will be home for 2 hours or more, turning the temperature down is worthwhile"

4.20 The 86R0S Demographic Information by Respondents' Attitudes Toward the Statement "Its hard for me to get around to making my home more energy efficient"

4.21 The 86ROS Demographic Information by Respondents' Attitudes Toward the Statement "People have a right to use as much energy as they want and can pay for"

4.22 The 86R0S Demographic Information by Respondents' Attitudes Toward the Statement "The price I first pay for the appliance

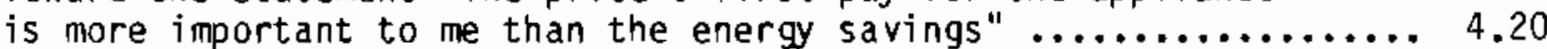

4.23 The 86R0S Demographic Information by Respondents' Attitudes Toward the Statement "To conserve enough energy to make a difference in my bills I would have to change my lifestyle" ...... 4.21

4.24 Reported Allocation of 1985 Total Household Income .............. 4.22

4.25 Reported Allocation of 1985 Total Household Income by Total Household Income 
,

. 


\section{D INTRODUCTION}

To better understand how electricity is used by the residential sector of the Pacific Northwest, the Bonneville Power Administration (BPA) is sponsoring the End-Use Load and Conservation Assessment Program (ELCAP). The purpose of this project is to measure not only the amount of electricity used by residential consumers, but also the time and the purposes for its use. During the past $f$ ew years information about the structural characteristics of the ELCAP dwellings, as well as the behavioral, attitudinal, and demographic characteristics of the occupants, has been collected using the Residential Occupant Survey-Mait (ROSM), the Residential Occupant Survey-Telephone (ROST) and the Residential Building Characteristics On-Site Inspection (RI). In support of this ongoing work, the BPA contracted with Pacific Northwest Laboratory (PNL) to develop and manage the Residential Occupant Survey-Spring '86 (86ROS). This survey was administered to dwellings in the BPA service area by Market Trends of Bellevue, Washington, during the spring of 1986.

The 86R0S survey had several objectives. The first was to update demographic and attitudinal data previously collected on the occupants of the ELCAP dwellings that had participated in the ROSM and/or the ROST. A second objective was to collect the same information on new occupants of ELCAP dwellings, where "new occupants" are those who moved into the ELCAP-metered dwelling after the administration of the ROST (summer, 1985). A third objective was to collect information that would be useful when combined with the metered data. For example, occupants were asked if they had any pets that are let out of the heated part of their home on a regular basis. If the response was affirmative, they were asked to estimate the number of times per day the pets are let out of the home. Since the opening of a door can result in a substantial heat loss, this information, when combined with the metered data, will be useful for developing energy-use profiles of the occupants.

The sample for the 86R0S consisted of two basic groups of dwellings: 1) metered dwellings in the ELCAP's Base Study and four Case Studies, and 2) the ELCAP metered dwellings also involved in the Residential Standards Demonstration Program (RSOP) Matched Homes study. Since most of these 
dwellings also participated in the ROSM and the ROST studies, it will be possible to track demographic and attitudinal changes over time by comparing the findings of these previous studies with the 86 R0S results.

This report provides information on the development and implementation of the 86R0S as well as selected descriptive results. Conclusions and recommendations are presented in Chapter 2.0. Chapter 3.0 contains a description of the survey design and its implementation. Results of the data analyses are presented in Chapter 4.0 . 


\subsection{CONCLUSIONS ANO RECOMMENDATIONS}

The demographic, attitudinal, and behavioral data collected by the 86ROS provides useful information related to the use and conservation of electricity in dwellings participating in one of the ELCAP studies. For example, the results show a positive correlation between reported indoor temperature and the age of the oldest resident. The results also show that older respondents (66 years or more) were twice as likely as younger respondents to report that their dwelling was as energy efficient as it could be.

In regards to living space not being heated, the results showed that almost $60 \%$ of the ELCAP occupants do not heat one or more rooms during the heating season. Also, almost $45 \%$ of the ELCAP dwellings were unoccupied for at least one week during the reporting period of a year. With this information, analysts may be able to make appropriate adjustments when analyzing aggregated energy consumption figures.

The 86ROS was the first of the residential occupant surveys to ask occupants to estimate what percentage of their total household income was allocated to different expenditure categories. The household energy expenses category yielded an unexpected result. The actual dollar amount spent for household energy expenses remained relatively constant over income levels.

Besides the analyses done for this report, the data collected in the 86ROS will be used to update the Fundamental Residential Characteristics data set for the ELCAP residences (Tocated within the ELCAP Characteristics Database). This data set is currently being developed from information selected by the ROSM, the ROST, and the RI. One major use of periodically-obtained survey information such as the 86ROS, the ROSM, and the ROST data is the ability to relate detailed electricity end-use patterns to socio-demographic characteristics of the household at different periods of time (when the household itself does not change by moving out). When new occupants move into an ELCAP metered dwelling, of course, the most recent periodic survey provides the only relevant set of information for the household in that dwelling. 
The 86R0S data, when combined with previous survey information, allows for analysis of the drift over time of characteristics of the current ELCAP sample. Changes in statistical bias from the characteristics of the targeted sample can be examined in this analysis. Further, the potential biasing impacts of sample degradation through the loss of the ELCAP metered houses from the program should be investigated, leading to an estimate of the loss associated with further reductions in the sample. For these reasons, new surveys with a similar set of tracking questions should be designed and implemented. Future surveys would also allow an opportunity to develop new and different questions to elicit more detailed information about the occupants of the ELCAP dwellings. 


\subsection{SURVEY DESIGN AND IMPLEMENTATION}

\subsection{INTRODUCTION}

This section of the report reviews the survey design process, the development of the survey sample frame, and the implementation of the survey. Problems encountered during implementation of the survey and actions taken to solve them are also discussed.

\subsection{SURVEY DESIGN}

The 86R0S survey was designed early in 1986 with assistance from staff at PNL and BPA. Because many of the survey participants had participated in the ROSM and the ROST surveys during the previous 13 months, the 86ROS survey was designed to be as unobtrusive and simple as possible. The survey was conducted by mail, instead of by telephone, and was limited to four pages.

There are two basic types of questions in the 86R0S. One type was designed to update demographic, attitudinat, and behavioral information previously collected on the occupants of the ELCAP dwellings. To track the occupants' responses over time, a subset of these types of questions was taken from the ROSM and the ROST. To ensure the reliability of responses between dwellings and over time, questions used from previous surveys were worded the same on the 86ROS.

To better understand residential consumers' electricity usage and conservation investment, two new questions were asked on the $86 \mathrm{R} 0 \mathrm{~S}$, that had not been asked on the ROSM or the ROST. One question asked the occupants how many times per day pets are let out of the heated part of their home. This information can be matched with the electricity usage data for the specific occupants of an ELCAP dwelling to develop a more accurate profile of the energy usage for the dwelling.

The other new question asked the occupants to estimate what percentage of their total combined income for 1985 was allocated to various necessities and 
living expenses. This information, especially the amount allocated to household energy, can be used in analyses when combined with information about the occupant's previous conservation investments.

\subsection{SURVEY SAMPLE}

The 86R0S was designed to survey only occupants of the ELCAP dwellings. The dwellings included in the 86R0S are either current participants in the ELCAP Base Study, in an ELCAP Case Study, or in the ELCAP metered sample of RSDP homes. The sampling frame for the 86R0S consisted of 429 ELCAP dwellings.

\subsection{SURVEY IMPLEMENTATION}

Market Trends, a research company located in Bellevue, Washington, was subcontracted to field the survey and to provide a data tape of survey responses. On April 23, 1986, surveys were sent to the 429 ELCAP dwellings. By May 15, 1986, 159, or 37\%, of the surveys had been completed and returned to Market Trends. On May 16, 1986, the 270 households from the original sample 1 ist, who had not returned the survey from the first mailing were sent a second survey. An additional 197 surveys were returned to Market Trends. Overa11, 356 of the 429 surveys were returned by June 18, 1986, giving an overall response rate of $83.0 \%$.

Survey responses were entered by Market Trends data entry personnel using OPUS-1, a data entry and tabulation program. The computer program permits the user to specify field lengths and a range of acceptable responses for each variable. Data from the survey were entered at two different times by two different data entry personnel. An OPUS-1 verification program was run which tries to match the two data files. The verification program produced an output file that indicated where the data did not match between the two files for each survey. At this point the original survey was reviewed and the possible errors were corrected. This procedure was repeated until there was a complete match between the surveys on both files.

A stratified random sample of surveys was selected for the error analysis. To perform the analysis, a binomial distribution had to be assumed for the possibility of errors. In other words, it was assumed that the data entry 
personnel were just as likely to make an error on one question as they were on another. Each survey contained 46 bits of information that needed to be entered. After comparing the sample of actual surveys to the data entered on the data tape, PNL found one error. Therefore, based on 36 surveys and 46 bits of information, an error rate of .06\% was estimated. Upon investigation, the one error appeared to be an error of interpretation by the data entry personne? rather than an incorrect typing of a number. With such an extremely low error rate, it is appropriate to assume that the data entered from the survey is accurate for analysis purposes.

Very few problems were associated with the implementation of the 86R0S. Three surveys were returned to Market Trends marked "addressee unknown" or "no mail receptacle." Each was remailed in a smaller envelope to the same address, but again, all three were returned. The ELCAP Site Relations coordinator at PNL was then contacted with this information. Another survey was returned incompleted with a note stating that the occupant had died.

Several respondents added comments or questions to their survey. Most frequently the respondents were questioning why certain types of information were needed. This occurred quite frequently for the income and income allocation questions. An interesting comment provided in response to the income allocation question was "Ridiculous-Like most everyone else with teenagers and cost of living--we just piug up the holes and be thankful we're able to do so most of the time. You want percentages?" Needless to say, the respondent did not provide the information. 
$\lambda$

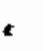

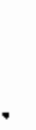




\subsection{RESULTS}

\subsection{INTRODUCTION}

This section of the report presents some initial results of data analyses conducted on the 86ROS findings. The intent of this discussion is to give a brief description of the current occupants in the ELCAP dwellings by presenting socio-demographic, behavioral, and attitudinal results. The results presented are based on self-reported information provided by the occupants and therefore may be biased.

\subsection{SOC10-DEMOGRAPHIC INFORMATION}

Table 4.1 presents frequencies and percentages of several sociodemographic variables. Almost $50 \%$ of the respondents and second householders are between the ages of 25 and 46 years old, and approximately $71 \%$ of the respondents on the 86 R0S were males.

The education level of the occupants of a dwelling can be an important factor not only in terms of understanding electricity usage in a dwelling but a) so for predicting which dwellings are most likely to invest in energy conservation measures in the future. To categorize the dwellings by education, the most formally educated adult occupant for whom the 86R0S contains data was used for each household. Over 50\% of the ELCAP dwellings contain adult occupants who have graduated from high school, and may have some college or posthigh school vocational education; approximately $45 \%$ of the dwellings contain an adult who has a college degree, or more education, and the remaining $5 \%$ contain adults who have not graduated from high school.

Approximately 55\% of the ELCAP dwellings have children living at home under 18 years of age. Over $85 \%$ of the dwellings have an occupant between the ages of 17 and 66 years $01 d$, and $17 \%$ of the dwellings have an occupant 66 years oid or older. The results show that for the ELCAP dwellings, two occupants was the most frequent size of househoid $(40.2 \%)$. Less than $10 \%$ of the dwellings have only one occupant while approximately $52 \%$ of the dwellings have three or more occupants. 
TABLE 4.1. 86ROS Socio-Demographic Information

Number of Percentage of

Dwellings Dwellings

Age of Respondent

- 25 years or less

- 26-45 years

176

$0.6 \%$

- 46-65 years

115

$49.9 \%$

- 66 years or more

Age of Second Householder

- 25 years or less

- 26-45 years

- 66 years or more

Age of Oldest Resident

- 25 years or less

- 26-45 years

- 46-65 years

- 66 years or more

Sex of Respondent

- Male

- Female

Sex of Second Householder

- Male

- Female

Education of Respondent

- Less than high school graduate

- High schopl graduate through some

- College degree or more

Education of Second Householder

- Less than high school graduate

- High schopl graduate through some

- College degree or more

84

$23.6 \%$ 
TABLE 4.1. (cont'd)

\begin{tabular}{|c|c|c|}
\hline & $\begin{array}{l}\text { Number of } \\
\text { Dwellings }\end{array}$ & $\begin{array}{r}\text { Percentage } \\
\text { Dwelling } \\
\end{array}$ \\
\hline \multicolumn{3}{|l|}{ Education of Most Educated Householder } \\
\hline $\begin{array}{l}\text { - Less than high school graduate } \\
\text { - High schogl graduate through some } \\
\text { coillege(a) } \\
\text { - College degree or more }\end{array}$ & $\begin{array}{r}14 \\
179 \\
155\end{array}$ & $\begin{array}{r}4.0 \% \\
51.4 \% \\
44.5 \%\end{array}$ \\
\hline \multicolumn{3}{|l|}{ Age of the Occupants } \\
\hline $\begin{array}{l}\text { - } 5 \text { years or less } \\
\text { - } 6-17 \text { years old } \\
\text { - } 18-65 \text { years old } \\
\text { - } 66 \text { years or older }\end{array}$ & $\begin{array}{r}79 \\
117 \\
307 \\
61\end{array}$ & $\begin{array}{l}22.2 \% \\
32.9 \% \\
86.2 \% \\
17.2 \%\end{array}$ \\
\hline
\end{tabular}

Number of Occupants

$-1$

$-2$

$-3$

$-4$

76

$15.4 \%$

- 5 or more

Employed Full-Time

- Both full-time or 1 fulltime--no second householder

- Two householders/one full-

112

$31.9 \%$ time, one not

- Both not full-time or one not full-time, no second householder

Total Household Income

- Less than $\$ 16,000$

- $\$ 16,000-\$ 34,999$

- $\$ 35,000$ or more

$\begin{array}{rl}51 & 14.4 \% \\ 144 & 40.4 \% \\ 132 & 37.1 \%\end{array}$

(a) "Some College" includes post high school vocational training.

The employment status of the occupants of a dwelling can be an important factor when attempting to predict energy use. Currently, 30\% of the ELCAP dwellings have all adult occupants working full-time. Almost $44 \%$ of the households have one adult occupant working full-time while the other adult 
occupant works part-time or not at all. Approximately $25 \%$ of the households have no adult occupants working full-time.

A relationship appears to exist between the age of the oldest occupant and the total household income, as is shown in Table 4.2. Between 40\% and 50\% of the dwellings with the oldest adults being 26 to 65 years old have a total household income of $\$ 35,000$ or more. There is a positive correlation between total household income and the education level of the most formally educated adult occupant. Approximately $57 \%$ of the households whose most formally educated adult has a college degree or more have a total household income of $\$ 35,000$ or more (see Table 4.3 ). These findings are not surprising since age

TABLE 4.2. Total Household Income by Age of the Residents

\begin{tabular}{|c|c|c|c|c|}
\hline \multirow[b]{2}{*}{$\begin{array}{c}\text { Total } \\
\text { Household Income }\end{array}$} & \multicolumn{4}{|c|}{ Age of Residents (a) } \\
\hline & $\begin{array}{c}25 \text { Years } \\
\text { or Less } \\
(n=2) \\
\end{array}$ & $\begin{array}{c}26-45 \\
\text { Years } \\
(n=16 I)\end{array}$ & $\begin{array}{r}46-65 \\
\text { Years } \\
(n=108) \\
\end{array}$ & $\begin{array}{l}66 \text { Years } \\
\text { or More } \\
(n=54)\end{array}$ \\
\hline Less than $\$ 16,000$ & $0.0 \%$ & 6.2 & 16.7 & $40.7 \%$ \\
\hline$\$ 16,000$ to $\$ 34,999$ & $0.0 \%$ & $46.6 \%$ & $39.8 \%$ & $44.4 \%$ \\
\hline$\$ 35,000$ or More & $0.0 \%$ & $47.2 \%$ & $43.5 \%$ & $14.8 \%$ \\
\hline
\end{tabular}

(a) Dwellings were categorized by age according to the oldest adult resident for whom the 86 ROS contains data.

TABLE 4.3. Total Household Income by Education Level

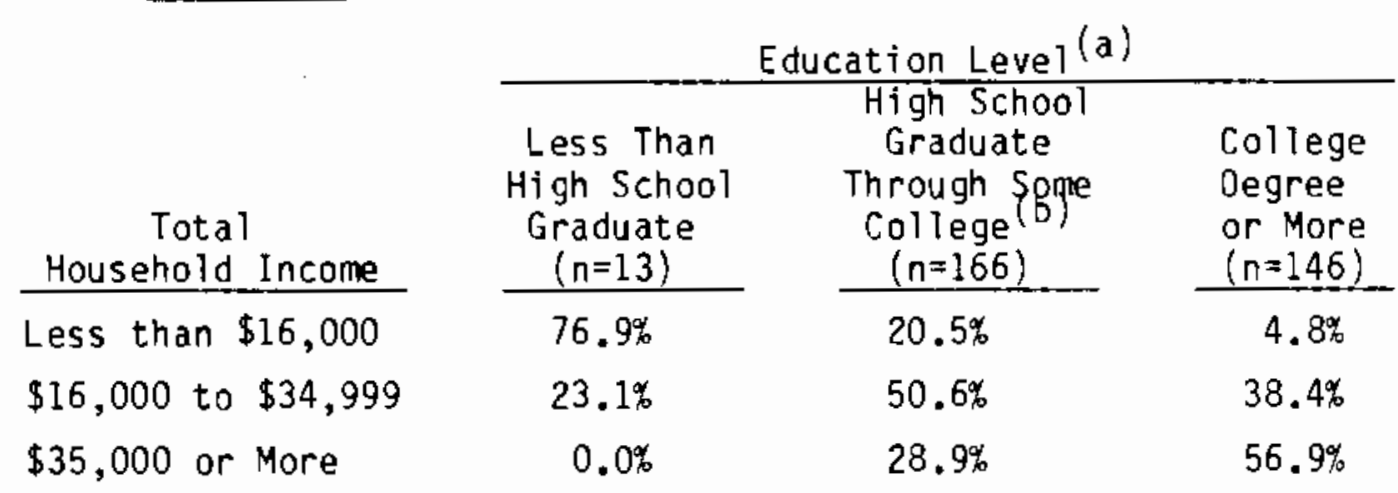

(a) Dwellings were categorized by education according to the most formally educated adult resident for whom the 86R0S contains data.

(b) "Some college" includes post high school vocational training. 
and education are usually related to income level. However, it does help to refine the picture of current ELCAP occupants.

\subsection{BEHAVIORAL INFORMATION}

Space heating loads during the winter months are strongly affected by how warm the dwellings are kept. Thus, occupants were asked what temperatures were maintained in the occupied space of their dwellings, while they were at home and awake, during the $1985 / 86$ heating season. A potential problem may exist with the results and the interpretation of them, if the respondents reported the temperature setting their thermostats were set at, as opposed to the actual room temperature. The possible problem could be checked by comparing the selfreported temperatures with the actual room temperatures collected by the internal temperature sensors located in each ELCAP residence. The temperatures that people keep their dwellings may, in turn, be related to other factors such as income, age, or sex. The results in Table 4.4, for example, indicate a positive correlation between indoor temperature and the age of the oldest resident. (Table 4.1 shows the frequencies and percentages for the sociodemographic variables used in this section.)

As a way to partially validate the indoor temperatures the occupants reported, Table 4.5 shows the reported temperatures and the respondent's attitudes toward being comfortable when the temperature in their home was $68^{\circ} \mathrm{F}$ or

TABLE 4.4. Temperature the Dwellings are Kept when the Household is Home and Awake by Age of the Residents

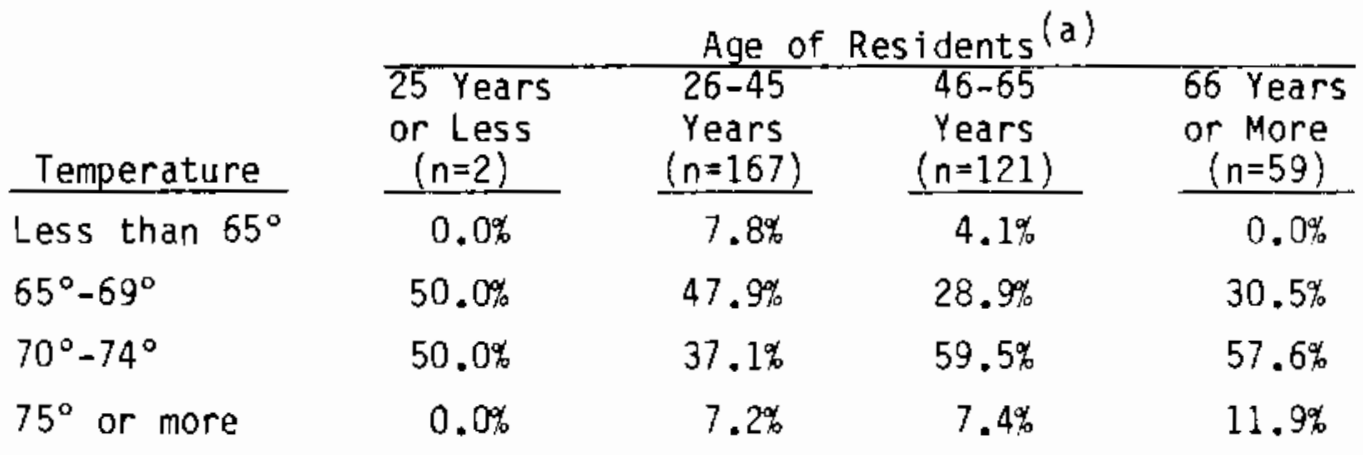

(a) Dwellings were categorized by age according to the oldest adult resident for whom the 86 Ros contains data. 
TABLE 4.5. Temperature the Dwellings are Kept when the Household is Home and Awake by Respondent's Attitude Toward the Statement "In the winter, I find it difficult to be comfortable when the temperature in my home is $68^{\circ} \mathrm{F}$ or less."

\begin{tabular}{|c|c|c|c|}
\hline Temperature & $\begin{array}{c}\text { Strongly Disagree } \\
\text { or Disagree } \\
(n=97)\end{array}$ & $\begin{array}{l}\text { Neutral } \\
(n=69)\end{array}$ & $\begin{array}{c}\text { Strongly Agree } \\
\text { or Agree } \\
(n=183) \\
\end{array}$ \\
\hline Less than $65^{\circ} \mathrm{F}$ & $11.3 \%$ & $7.3 \%$ & $1.1 \%$ \\
\hline $65^{\circ}-69^{\circ}$ & $67.0 \%$ & $53.6 \%$ & $17.5 \%$ \\
\hline $70^{\circ}-74^{\circ}$ & $21.7 \%$ & $39.1 \%$ & $66.1 \%$ \\
\hline $75^{\circ}$ or more & $0.0 \%$ & $0.0 \%$ & $15.3 \%$ \\
\hline
\end{tabular}

1ess. As expected, occupants who kept the indoor temperature of their dwel1ings above $68^{\circ} \mathrm{F}$ reported difficulty in being comfortable when the temperature in their home was $68^{\circ} \mathrm{F}$ or less.

Another factor that affects the energy consumption in a dwelling is whether the occupants choose to not heat some of the rooms in their dwellings during the months when heating is necessary. The frequencies and percentages of rooms not heated are shown in Table 4.6. ATmost $60 \%$ of the current ELCAP occupants reported not heating at least one room in their dwelling during the heating season. Not heating one or more bedrooms (65.1\%) was the most frequent

TABLE 4.6. Dwellings with Unheated Rooms ( $n=205)$

\begin{tabular}{|c|c|c|}
\hline Unheated Rooms & $\begin{array}{l}\text { Number of } \\
\text { Dwellings } \\
\end{array}$ & $\begin{array}{c}\text { Percentage of } \\
\text { Dwellings }\end{array}$ \\
\hline Bedroom & 134 & $65.4 \%$ \\
\hline Bathroom & 57 & $27.8 \%$ \\
\hline Other small room & 35 & $17.1 \%$ \\
\hline Den/study & 17 & $8.3 \%$ \\
\hline Other large room & 15 & $7.3 \%$ \\
\hline Family/recreation room & 12 & $5.9 \%$ \\
\hline Dining room & 4 & $2.0 \%$ \\
\hline Living room & 4 & $2.0 \%$ \\
\hline Kitchen without eating area & 3 & $1.5 \%$ \\
\hline Kitchen with eating area & 2 & $1.0 \%$ \\
\hline
\end{tabular}


choice of room type, followed by bathrooms (28.0\%). Of those occupants that do not heat some of their rooms during the heating season, less than $2 \%$ of them close off the dining room, living room, or the kitchen (with or without an eating area).

It is also important to know if the dwelling was unoccupied for any durations of time. If a dwelling was unoccupied for several weeks during the year, the aggregated energy consumption of the dwelling for that year would effect the development of forecasting models for energy conservation. By knowing how Tong the dwelling was unoccupied during a given year the results can be adjusted. The 86ROS survey asked the respondents to indicate any periods of at least one week, since May 1, 1985, when they did not use any of their appliances, heating or cooling equipment, or other large equipment. Almost $45 \%$ of the dwellings were unoccupied for at least one week during the reporting period. Of those dwellings, over 50\% were unoccupied for one week, approximately $20 \%$ were unoccupied for two weeks, $18 \%$ for three weeks, and $8 \%$ for four weeks or more (see Table 4.7).

As previously mentioned, one of the objectives of the 86R0S survey was to collect information that would help to better develop energy usage profiles when combined with the metered data. Since the opening of a door in a heated part of the dwelling can result in a substantial amount of heat loss, the respondents were asked whether they had any pets that were regularly let out of the heated part of their home and, if so, how frequently. Approximately $42 \%$ of the current occupants do not have pets and another $5 \%$ have pets but do not let them out of the home on a regular basis. Of those residents that let their

TABLE 4.7. Dwellings that were Unoccupied for at Least One Week $(n=156)$

\begin{tabular}{lccc}
$\begin{array}{c}\text { Number of } \\
\text { Weeks Unoccupied }\end{array}$ & & $\begin{array}{c}\text { Number of } \\
\text { Dwellings }\end{array}$ & $\begin{array}{c}\text { Percentage of } \\
\text { Responses }\end{array}$ \\
\cline { 1 - 1 } Dne & 82 & $52.6 \%$ \\
Two & 33 & $21.2 \%$ \\
Three & 28 & $17.9 \%$ \\
Four or More & 13 & $8.3 \%$
\end{tabular}


pets out on a regular basis, over 50\% do so 1 to 4 times per day. Letting pets out 5 to 10 times per day was the next most frequent category $(35.6 \%)$, as shown in Table 4.8 .

\subsection{ATTITUDINAL INFORMATION}

An occupant's perception of the energy efficiency of their dwelling can be an important variable when segmenting the population into those most likely to invest in energy conservation measures. For example, if an occupant feels his home is about as energy efficient as it can be, then expectations for future conservation investment in the dwelling would likely be low. It may be more appropriate to target marketing efforts to occupants who had positive attitudes toward conservation investments and felt that moderate or major conservation improvements could be made. This, of course, will be affected by other factors such as total household income. Therefore, to focus marketing efforts for conservation investments, it is important to look not only at the occupants' perception of the energy efficiency of their dwelling but how these perceptions vary according to several other demographic, attitudinat, and behavioral variables.

A relationship appears to exist between the respondents' perception of their dwellings' energy efficiency and the respondent's age. Respondents 66 years old or more were more than two times as likely as younger respondents to state that their dwellings were as energy efficient as they could be (see Table 4.9.) (Table 4.1 shows the frequencies and percentages for the sociodemographic variables used in this section.)

TABLE 4.8. Number of Times a Day Pets are Let Out of the Heated Part of the Dwelling $(n=188)$

\begin{tabular}{|c|c|c|}
\hline $\begin{array}{l}\text { Number of Times } \\
\text { Pets are Let Out }\end{array}$ & $\begin{array}{l}\text { Number of } \\
\text { Dwellings }\end{array}$ & $\begin{array}{c}\text { Percentage of } \\
\text { Dwellings }\end{array}$ \\
\hline 1-4 times per day & 100 & $53.2 \%$ \\
\hline 5-10 times per day & 67 & $35.6 \%$ \\
\hline 11 times or more per day & 15 & $8.0 \%$ \\
\hline $\begin{array}{l}\text { Pets use a pet door or } \\
\text { crawl space }\end{array}$ & 6 & $3.2 \%$ \\
\hline
\end{tabular}


TABLE 4.9. Perceived Energy Efficiency of Occupants Home by Respondent's Age

\begin{tabular}{|c|c|c|c|c|}
\hline Perceived Energy Efficiency & $\begin{array}{l}25 \text { Years } \\
\text { or Less } \\
(n=2) \\
\end{array}$ & \begin{tabular}{l}
\multicolumn{2}{c}{ Respon } \\
$26-45$ \\
Years \\
$(n=170)$
\end{tabular} & $\begin{array}{l}t^{\prime} s \text { Age } \\
4 \overline{6}-65 \\
\text { Years } \\
(n=111)\end{array}$ & $\begin{array}{l}66 \text { Years } \\
\text { or More } \\
(n=59) \\
\end{array}$ \\
\hline As efficient as it can be & $0.0 \%$ & $11.18 \%$ & $15.32 \%$ & $33.90 \%$ \\
\hline $\begin{array}{l}\text { A little improvement can be } \\
\text { made }\end{array}$ & $0.0 \%$ & $49.41 \%$ & $43.24 \%$ & $38.98 \%$ \\
\hline $\begin{array}{l}\text { A moderate amount of } \\
\text { improvement can be made }\end{array}$ & $100.0 \%$ & $28.24 \%$ & $29.73 \%$ & $27.12 \%$ \\
\hline $\begin{array}{l}\text { A lot of improvement can be } \\
\text { made }\end{array}$ & $0.0 \%$ & $11.18 \%$ & $11.71 \%$ & $0.0 \%$ \\
\hline
\end{tabular}

No clear relationship is apparent between the respondent's perception of his/her dwelling's energy efficiency and his/her level of education. The majority of respondents in each category of education felt that "a little improvement" was the choice that best described the energy efficiency of their dwelling. Table 4.10 shows how the respondent's perception of dwelling energy efficiency corresponds to education level.

TABLE 4.10. Perceived Energy Efficiency of 0ccupant's Home by Respondent's Level of Education

\begin{tabular}{|c|c|c|c|}
\hline Perceived Energy Efficiency & $\begin{array}{l}\text { Less Than } \\
\text { High School } \\
\text { Graduate } \\
(n=26) \\
\end{array}$ & $\begin{array}{c}\text { High School } \\
\text { Graduate } \\
\text { Through Some } \\
\text { College } \\
(n=173)\end{array}$ & $\begin{array}{l}\text { College } \\
\text { Degree } \\
\text { or More } \\
(n=139) \\
\end{array}$ \\
\hline As efficient as it can be & $34.6 \%$ & $16.8 \%$ & $13.0 \%$ \\
\hline $\begin{array}{l}\text { A little improvement can be } \\
\text { made }\end{array}$ & $38.5 \%$ & $40.5 \%$ & $51.8 \%$ \\
\hline $\begin{array}{l}\text { A moderate amount of } \\
\text { improvement can be made }\end{array}$ & $15.4 \%$ & $32.4 \%$ & $27.3 \%$ \\
\hline $\begin{array}{l}\text { A lot of improvement can be } \\
\text { made }\end{array}$ & $11.5 \%$ & $10.4 \%$ & $7.9 \%$ \\
\hline
\end{tabular}

(a) "Some college" includes post-high school vocational training. 
As with education, no clear relationship is apparent between the employment status of the dwellings' occupants and the respondents' perceptions of the energy efficiency of the dwelling. (See Table 4.11.) It may be interesting to note that occupants of dwellings with no adult occupants employed full-time were most likely to state that their home is about as energy efficient as it could be. This finding may be partially explained if these occupants are retired and have already made energy improvements to their home. Otherwise employment status did not seem to affect the respondent's perceptions.

A relationship appears to exist between the respondents' perceived energy efficiency of their dwellings and the total household income, as can be seen in Table 4.12. Households with incomes of $\$ 35,000$ or more were somewhat more likely to state that their dwellings were as energy efficient as they could be or only a little improvement could be made than households with smaller incomes. Table 4.13 shows the breakdown between the respondents' perceptions of the energy efficiency of their dwellings and the temperature the dwellings are kept when the household is home and awake. Approximately $60 \%$ of the

TABLE 4.11. Perceived Energy Efficiency of Dwelling by Employment Status of Dccupants

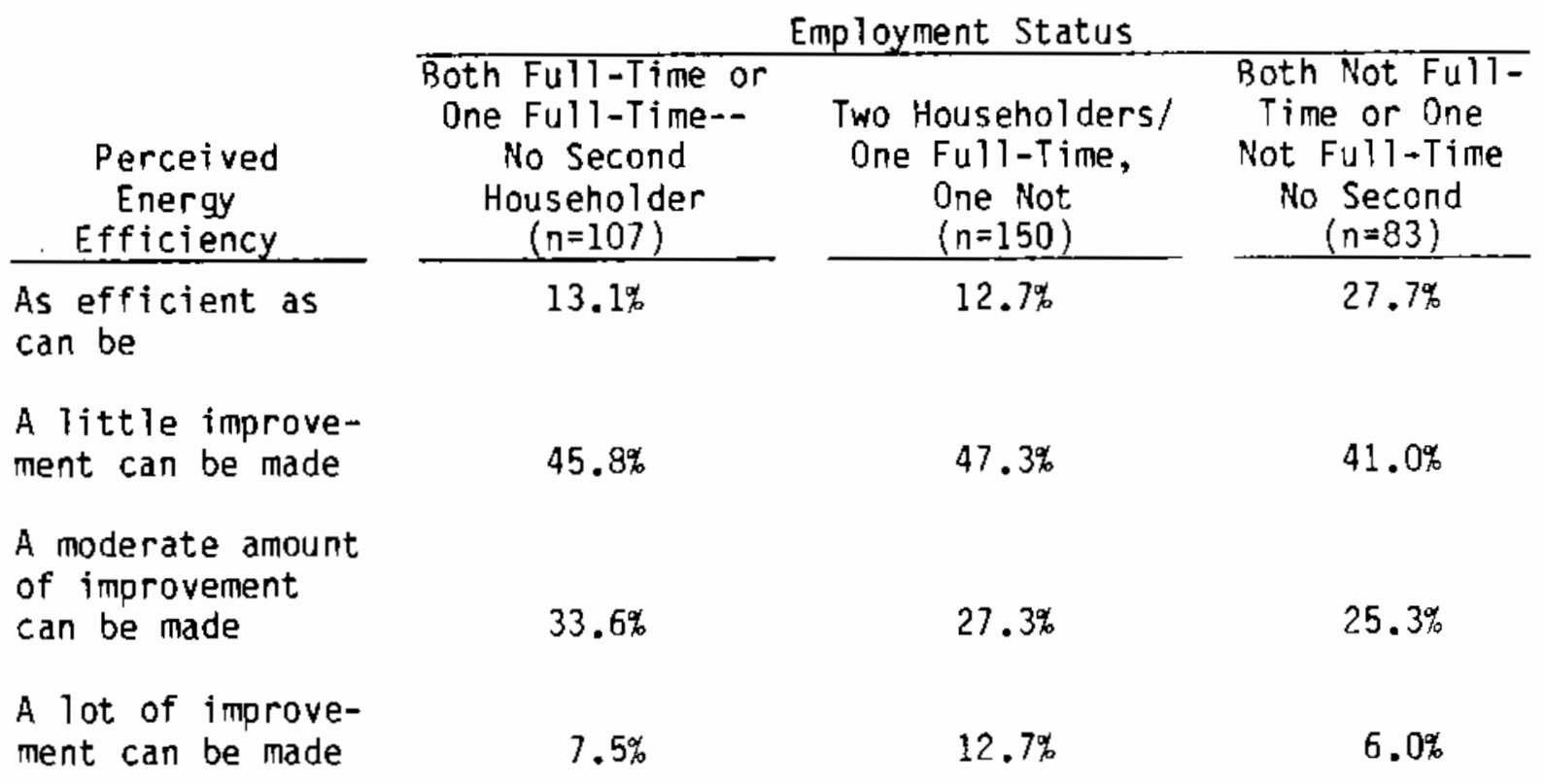


TABLE 4.12. Perceived Energy Efficiency of Occupant's Home by Total Household Income

\begin{tabular}{|c|c|c|c|}
\hline \multirow[b]{2}{*}{ Perceived Energy Efficiency } & \multicolumn{3}{|c|}{ Total Household Income } \\
\hline & $\begin{array}{c}\text { Less Than } \\
\$ 16,000 \\
(n=49) \\
\end{array}$ & $\begin{array}{c}\$ 16,000 \text { to } \\
\$ 34,999 \\
(n=140) \\
\end{array}$ & $\begin{array}{l}\$ 35,000 \\
\text { or more } \\
(n=129) \\
\end{array}$ \\
\hline As efficient as it can be & $26.5 \%$ & $12.1 \%$ & $15.5 \%$ \\
\hline $\begin{array}{l}\text { A little improvement can be } \\
\text { made }\end{array}$ & $30.6 \%$ & $40.7 \%$ & $53.5 \%$ \\
\hline $\begin{array}{l}\text { A moderate amount of } \\
\text { improvement can be made }\end{array}$ & $34.7 \%$ & $35.0 \%$ & $23.3 \%$ \\
\hline $\begin{array}{l}\text { A lot of improvement can be } \\
\text { made }\end{array}$ & $8.2 \%$ & $12.1 \%$ & $7.8 \%$ \\
\hline
\end{tabular}

TABLE 4.13. Perceived Energy Efficient of Occupant's Home by Temperature the Dwellings are Kept When the Household is Home and Awake

\begin{tabular}{|c|c|c|c|c|}
\hline \multirow[b]{2}{*}{ Perceived Energy Efficiency } & \multicolumn{4}{|c|}{ Temperature } \\
\hline & $\begin{array}{c}\text { Less Than } \\
65^{\circ} \mathrm{F} \\
(n=18) \\
\end{array}$ & $\begin{array}{r}65-69^{\circ} \mathrm{F} \\
(\mathrm{n}=128) \\
\end{array}$ & $\begin{array}{l}70-74^{\circ} \mathrm{F} \\
(n=167) \\
\end{array}$ & $\begin{array}{l}75^{\circ} \mathrm{F} \text { or } \\
\text { More } \\
(n=28) \\
\end{array}$ \\
\hline As efficient as it can be & $16.7 \%$ & $15.6 \%$ & $16.8 \%$ & $14.3 \%$ \\
\hline $\begin{array}{l}\text { A little improvement can be } \\
\text { made }\end{array}$ & $44.4 \%$ & $46.9 \%$ & $43.7 \%$ & $50.0 \%$ \\
\hline $\begin{array}{l}\text { A moderate amount of } \\
\text { improvement can be made }\end{array}$ & $33.3 \%$ & $28.1 \%$ & $29.9 \%$ & $28.6 \%$ \\
\hline $\begin{array}{l}\text { A lot of improvement can be } \\
\text { made }\end{array}$ & $5.6 \%$ & $9.4 \%$ & $9.6 \%$ & $7.1 \%$ \\
\hline
\end{tabular}

dwellings at each of the temperature categories had respondents report that their dwellings were as energy efficient as they could be or a little improvement could be made.

Respondents were asked on the 86R0S to specify what percentage of their total 1985 household income was allocated to each of several different categories. One category was household energy, which could include the cost of utility bills and money spent on conservation improvements. Table 4.14 compared the respondents' perceptions of the energy efficiency of their dwellings to the 
TABLE 4.14. Perceived Energy Efficiency of Occupant's Home by Amount of 1985 Total Household Income Allocated to Household Energy Expenses

\begin{tabular}{|c|c|c|c|c|c|}
\hline \multirow[b]{2}{*}{ Perceived Energy Efficiency } & \multicolumn{5}{|c|}{ Allocations to Household Energy Expenses } \\
\hline & $\begin{array}{r}0 \% \\
(n=6) \\
\end{array}$ & $\begin{array}{r}1 \%-10 \% \\
(n=159)\end{array}$ & $\begin{array}{r}11 \%-20 \% \\
(n=74) \\
\end{array}$ & $\begin{array}{r}21 \%-30 \% \\
(n=16) \\
\end{array}$ & $\begin{array}{c}31 \% \text { or } \\
\text { More } \\
(n=7)\end{array}$ \\
\hline As efficient as it can be & $16.7 \%$ & $14.5 \%$ & $10.8 \%$ & $18.8 \%$ & $57.1 \%$ \\
\hline $\begin{array}{l}\text { A little improvement can be } \\
\text { made }\end{array}$ & $50.0 \%$ & $45.3 \%$ & $41.9 \%$ & $43.8 \%$ & $14.3 \%$ \\
\hline $\begin{array}{l}\text { A moderate amount of } \\
\text { improvement can be made }\end{array}$ & $33.3 \%$ & $28.9 \%$ & $32.4 \%$ & $32.3 \%$ & $28.6 \%$ \\
\hline $\begin{array}{l}\text { A lot of improvement can be } \\
\text { made }\end{array}$ & $0.0 \%$ & $11.3 \%$ & $14.9 \%$ & $6.3 \%$ & $0.0 \%$ \\
\hline
\end{tabular}

percentage of income that was allocated by the respondents to household energy expenses. Those occupants that allocated $31 \%$ or more of their total househoid income to household energy expenses were the most likely group to report that their dwellings were about as energy efficient as they could be; however, if this category is combined with those that felt a little improvement could be made, the distinction between the different allocation amounts decreases.

Another way to estimate the likelihood of occupants investing in any energy conservation measures is to compare their perceptions of the dwelling's energy efficiency by their attitudes toward making their dwellings more energy efficient. The results of this comparison, as shown in Table 4.15 , indicate that those who feel a moderate amount or a lot of improvement could be done to their dwellings also felt that it is hard for them to get around to making their dwellings more energy efficient. Considering these results it would be interesting to delve further into the reason(s) why the occupants find it hard to get around to making their homes more energy efficient. This information could be useful when developing energy conservation marketing programs.

To better understand energy usage patterns, it is important to look at the occupants' attitudes toward conservation and energy usage. This information, combined with demographic and behavioral results, can give a broader and more detailed picture of energy usage profiles. 0ccupants' attitudes can affect 
TABLE 4.15. Perceived Energy Efficiency of Occupant's Home by Respondents Attitude Toward the Statement "It's hard for me to get around to maxing my home more energy efficient"

\begin{tabular}{|c|c|c|c|}
\hline Perceived Energy Efficiency & $\begin{array}{c}\text { Strongly Disagree } \\
\text { or Disagree } \\
(n=122)\end{array}$ & $\begin{array}{r}\text { Neutral } \\
(n=95) \\
\end{array}$ & $\begin{array}{l}\text { Strongly Agree } \\
\text { or Agree } \\
(n=117)\end{array}$ \\
\hline As efficient as can be & $24.8 \%$ & $8.4 \%$ & $12.8 \%$ \\
\hline $\begin{array}{l}\text { A little improvement can be } \\
\text { made }\end{array}$ & $51.6 \%$ & $51.6 \%$ & $35.0 \%$ \\
\hline $\begin{array}{l}\text { A moderate amount of } \\
\text { improvement can be made }\end{array}$ & $19.7 \%$ & $29.5 \%$ & $38.5 \%$ \\
\hline $\begin{array}{l}\text { A lot of improvement can be } \\
\text { made }\end{array}$ & $4.1 \%$ & $10.5 \%$ & $13.7 \%$ \\
\hline
\end{tabular}

motivation to participate in conservation practices or to invest in conservation measures. Therefore, eight attitude statements concerning energy usage and conservation practices were included on the 86R0S. Each of these attitude statements has been broken down by the respondent's age, sex, and education level as well as the total household income for 1985.

The highest levels of agreement for the statement, "In the winter, I find it difficult to be comfortable when the temperature in my home is $68^{\circ} \mathrm{F}$ or less" came from those respondents 66 years or older, those having less than a high school education, and those with a total household income of less than $\$ 16,000$. (See Table 4.16.) Almost $70 \%$ of those respondents with less than a high school education agreed with the statement, "Reducing the temperature of the water heater from $140^{\circ} \mathrm{F}$ to $120^{\circ} \mathrm{F}$ saves enough energy to make it worth doing". (See Table 4.17.) Oniy 50\% of those who had graduated from high school and may have had some additional education, and $58 \%$ of those with a college degree were likely to agree that turning the water temperature down was worthwhile.

Total household income was the primary variable to differentiate respondents for the statement, "The main reason to conserve energy is to save money". Table 4.18 demonstrates that the likelihood of agreeing with the statement was negatively correlated with level of household income. Almost $70 \%$ of the respondents with incomes less than $\$ 16,000$ agreed with the statement, while 
TABLE 4.16. The 86ROS Demographic Information by Respondents' Attitudes Toward the Statement "In the winter I find it difficult to be comfortable when the temperature in my home is $68^{\circ} \mathrm{F}$ or less"

\begin{tabular}{|c|c|c|c|}
\hline & $\begin{array}{l}\text { Strongly Disagree } \\
\text { or Disagree } \\
\end{array}$ & Neutral & $\begin{array}{c}\text { Strongly Agree } \\
\text { or Agree } \\
\end{array}$ \\
\hline \multicolumn{4}{|l|}{ Age of Respondent } \\
\hline $\begin{array}{lr}\text { - } 25 \text { years or less } & (n=2) \\
\text { - } 26-45 \text { years } & (n=175) \\
-46-65 \text { years } & (n=115) \\
\text { - } 66 \text { years or more } & (n=59)\end{array}$ & $\begin{array}{l}50.0 \% \\
34.9 \% \\
20.9 \% \\
17.0 \%\end{array}$ & $\begin{array}{r}0.0 \% \\
22.3 \% \\
18.3 \% \\
15.3 \%\end{array}$ & $\begin{array}{l}50.0 \% \\
42.9 \% \\
60.9 \% \\
67.8 \%\end{array}$ \\
\hline \multicolumn{4}{|l|}{ Sex of Respondent } \\
\hline $\begin{array}{l}\text { - Male } \\
\text { - Female }\end{array}$ & $\begin{array}{l}28.0 \% \\
26.5 \%\end{array}$ & $\begin{array}{l}20.0 \% \\
18.6 \%\end{array}$ & $\begin{array}{l}52.0 \% \\
54.9 \%\end{array}$ \\
\hline \multicolumn{4}{|l|}{ Education of Respondent } \\
\hline $\begin{array}{l}\text { - Less than high school } \\
\text { graduate } \quad(n=27) \\
\text { - High school graduate } \\
\text { through sgme } \\
\text { college (a) } \quad(n=178) \\
\text { - College degree or } \\
\text { more } \quad(n=141)\end{array}$ & $\begin{array}{l}22.5 \% \\
35.5 \%\end{array}$ & $20.2 \%$ & $\begin{array}{l}57.3 \% \\
45.4 \%\end{array}$ \\
\hline \multicolumn{4}{|l|}{ Total Household Income } \\
\hline $\begin{array}{lll}\text { - Less than } \$ 16,000 & (n=50) \\
\text { - } \$ 16,000-\$ 34,999 & (n=143) \\
\text { - } \$ 35,000 \text { or more } & (n=132)\end{array}$ & $\begin{array}{l}22.0 \% \\
26.6 \% \\
30.3 \%\end{array}$ & $\begin{array}{l}14.0 \% \\
23.1 \% \\
17.4 \%\end{array}$ & $\begin{array}{l}64.0 \% \\
50.4 \% \\
52.3 \%\end{array}$ \\
\hline
\end{tabular}

(a) "Some college" includes post high school vocational training.

approximately $58 \%$ of those with an income of $\$ 16,000$ to $\$ 34,999$ and $50 \%$ with an income of $\$ 35,000$ or more agreed with the statement.

The age of the respondent had a large effect on the responses to the attitude statement, "Ouring the winter, when no one will be home for 2 hours or more, turning the temperature down is worthwhile." Respondents were much less likely to feel that it is worthwhile to turn the temperature down as their age increased (see Table 4.19). Almost $60 \%$ of those 26 to 45 years old agreed with the statement, while $52 \%$ of those 46 to 65 years old agreed, and $45 \%$ of those 66 years or older agreed. 
TABLE 4.17. The 86R0S Demographic Information by Respondents' Attitudes Toward the Statement "Reducing the temperature of the water heater from $140^{\circ} \mathrm{F}$ to $120^{\circ} \mathrm{F}$ ' săve's" enough energy to make it worth doing"

\begin{tabular}{|c|c|c|c|}
\hline & $\begin{array}{c}\text { Strongly Disagree } \\
\text { or Disagree } \\
\end{array}$ & Neutra] & $\begin{array}{l}\text { Strongly Agree } \\
\text { or Agree }\end{array}$ \\
\hline \multicolumn{4}{|l|}{ Age of Respondent } \\
\hline $\begin{array}{ll}\text { - } 25 \text { years or less } & (n=2) \\
-26-45 \text { years } & (n=175) \\
\text { - } 46-65 \text { years } & (n=111) \\
\text { - } 66 \text { years or more } & (n=56)\end{array}$ & $\begin{array}{r}0.0 \% \\
16.0 \% \\
18.9 \% \\
23.2 \%\end{array}$ & $\begin{array}{r}100.0 \% \\
30.3 \% \\
22.5 \% \\
28.6 \%\end{array}$ & $\begin{array}{r}0.0 \% \\
53.7 \% \\
58.6 \% \\
48.2 \%\end{array}$ \\
\hline \multicolumn{4}{|l|}{ Sex of Respondent } \\
\hline $\begin{array}{lr}\text { - Male } & (n=246) \\
\text { - Female } & (n=99)\end{array}$ & $\begin{array}{l}18.3 \% \\
17.2 \%\end{array}$ & $\begin{array}{l}26.4 \% \\
31.3 \%\end{array}$ & $\begin{array}{l}55.3 \% \\
51.5 \%\end{array}$ \\
\hline \multicolumn{4}{|l|}{ Education of Respondent } \\
\hline $\begin{array}{l}\text { - Less than high school } \\
\text { graduate } \quad(n=26) \\
\text { - High school graduate } \\
\text { through some } \\
\text { college } \quad(n=177) \\
\text { - College degree or } \quad(n=137) \\
\text { more } \quad(n)\end{array}$ & $\begin{array}{l}18.1 \% \\
19.0 \%\end{array}$ & $31.6 \%$ & $50.3 \%$ \\
\hline \multicolumn{4}{|l|}{ Total Household Income } \\
\hline $\begin{array}{l}\text { - Less than } \$ 16,000 \quad(n=49) \\
\text { - } \$ 16,000-\$ 34,999 \quad(n=140) \\
\text { - } \$ 35,000 \text { or more } \quad(n=130)\end{array}$ & $\begin{array}{l}18.4 \% \\
15.7 \% \\
18.5 \%\end{array}$ & $\begin{array}{l}24.5 \% \\
28.6 \% \\
29.2 \%\end{array}$ & $\begin{array}{l}57.1 \% \\
55.7 \% \\
52.3 \%\end{array}$ \\
\hline
\end{tabular}

(a) "Some college" includes post high school vocational training.

Responses to the statement "It's hard for me to get around to making my home more energy efficient" varied by the age and education level of the respondent as well as the total household income. (See Table 4.20.) The respondents that tended to disagree were 45 years or less, had graduated from high school and may have had some college, and had an income of $\$ 35,000$ or more.

Age and education of the respondent and total household income also varied for the statement, "People have a right to use as much energy as they want and 
TABLE 4.18. The 86R0S Demographic Information by Respondents' Attitudes Toward the Statement "The main reason to conserve energy is to save money"

Age of Respondent

Strongly Disagree

or Disagree.

- 25 years or less $(n=2)$

- 26-45 years $\quad(n=176)$

- 46-65 years $\quad(n=115)$

- 66 years or more $(n=57)$

Sex of Respondent

- Male

- Female

$(n=101)$
$0.0 \%$

$12.5 \%$

$19.1 \%$

$15.8 \%$
$14.8 \%$
Neutral

$0.0 \%$

$32.4 \%$

$19.1 \%$

$31.6 \%$
Strongly Agree

or Agree

$100.0 \%$

$55.15 \%$

$61.7 \%$

$52.6 \%$

Education of Respondent

- Less than high school graduate

$(n=26)$

$27.2 \%$

$29.7 \%$

$58.0 \%$

$54.5 \%$

- High school graduate through some college (a)

$(n=178)$

- College degree or more $(n=141)$

$19.2 \%$

$19.2 \%$

$61.5 \%$

$14.6 \%$

$32.0 \%$

$53.4 \%$

$13.5 \%$

$26.2 \%$

$60.3 \%$

Total Household Income

- Less than $\$ 16,000 \quad(n=48)$

- \$16,000-\$34,999 (n=144)

- \$35,000 or more $\quad(n=132)$

$8.3 \%$

$16.7 \%$

$16.7 \%$
$22.9 \%$

$25.7 \%$

$33.3 \%$
$68.8 \%$

$57.6 \%$ $50.0 \%$

(a) "Some college" includes post high school vocational training.

can pay for." (See Table 4.21.) Those most in agreement were 66 years or older, had less than a high school education and had an income of less than $\$ 16,000$.

The price of an appliance seemed more important than its energy savings to respondents 66 years or older and to males. (See Table 4.22.) This finding is in response to the statement, "The price I first pay for the appliance is more important to me than the energy savings."

Almost $60 \%$ of the respondents 66 years or older agreed with the statement "To conserve enough energy to make a difference in my bills I would have to change my lifestyle." (See Table 4.23.) This is also the same segment of 
TABLE 4.19. The 86ROS Demographic Information by Respondents' Attitudes Toward the Statement "During the winter, when no one will be home for 2 hours or more, turning the temperature down is worthwhile"

\begin{tabular}{|c|c|c|c|}
\hline & $\begin{array}{l}\text { Strongly Disagree } \\
\text { or Disagree } \\
\end{array}$ & Neutral & $\begin{array}{l}\text { Strongly Agree } \\
\text { or Agree } \\
\end{array}$ \\
\hline \multicolumn{4}{|l|}{ Age of Respondent } \\
\hline $\begin{array}{lr}\text { - } 25 \text { years or less } & (n=2) \\
\text { - } 26-45 \text { years } & (n=175) \\
\text { - } 46-65 \text { years } & (n=114) \\
\text { - } 66 \text { years or more } \quad(n=56)\end{array}$ & $\begin{array}{r}0.0 \% \\
24.0 \% \\
30.7 \% \\
44.6 \%\end{array}$ & $\begin{array}{r}100.0 \% \\
17.1 \% \\
17.5 \% \\
10.7 \%\end{array}$ & $\begin{array}{r}0.0 \% \\
58.9 \% \\
51.8 \% \\
44.6 \%\end{array}$ \\
\hline \multicolumn{4}{|l|}{ Sex of Respondent } \\
\hline $\begin{array}{ll}\text { - Male } & (n=247) \\
\text { - Female } & (n=101)\end{array}$ & $\begin{array}{l}30.4 \% \\
26.7 \%\end{array}$ & $\begin{array}{l}17.0 \% \\
16.8 \%\end{array}$ & $\begin{array}{l}52.6 \% \\
56.4 \%\end{array}$ \\
\hline \multicolumn{4}{|l|}{ Education of Respondent } \\
\hline $\begin{array}{l}\text { - Less than high school } \\
\text { graduate } \quad(n=26) \\
\text { - High school graduate } \\
\text { through some } \\
\text { college }(a) \quad(n=176) \\
\text { - College degree or } \\
\text { more } \quad(n=140)\end{array}$ & $28.4 \%$ & $15.9 \%$ & $52.8 \%$ \\
\hline \multicolumn{4}{|l|}{ Total Household Income } \\
\hline $\begin{array}{l}\text { - Less than } \$ 16,000 \quad(n=49) \\
\text { - } \$ 16,000-\$ 34,999 \quad(n=141) \\
\text { - } \$ 35,000 \text { or more } \quad(n=131)\end{array}$ & $\begin{array}{l}32.7 \% \\
27.0 \% \\
29.8 \%\end{array}$ & $\begin{array}{l}20.4 \% \\
17.7 \% \\
15.3 \%\end{array}$ & $\begin{array}{l}46.9 \% \\
55.3 \% \\
55.0 \%\end{array}$ \\
\hline
\end{tabular}

(a) "Some college" includes post high school vocational training.

respondents that were more likely to state that it is difficult to get around to making their home more energy efficient. Those respondents with less than a high school degree were also more likely to feel that they would have to change their lifestyle to conserve enough energy to make a difference in their bills. Again, these results may be related to household income levels.

\subsection{ALLOCATION OF TOTAL HOUSEHOLD INCOME}

On past surveys respondents have always been asked what their total household income was for a particular year. It was decided to go beyond this and ask the respondents to estimate what percentages of their total household 
TABLE 4.20. The 86ROS Demographic Information by Respondents' Attitudes Toward the Statement "It's hard for me to get around to making my home more energy efficient"

\begin{tabular}{|c|c|c|c|}
\hline & $\begin{array}{l}\text { Strongly Disagree } \\
\text { or Disagree } \\
\end{array}$ & Neutral & $\begin{array}{c}\text { Strongly Agree } \\
\text { or Agree }\end{array}$ \\
\hline \multicolumn{4}{|l|}{ Age of Respondent } \\
\hline $\begin{array}{lr}\text { - } 25 \text { years or less } \quad(n=2) \\
\text { - } 26-45 \text { years } & (n=173) \\
\text { - } 46-65 \text { years } & (n=112) \\
\text { - } 66 \text { years or more } & (n=54)\end{array}$ & $\begin{array}{r}100.0 \% \\
41.0 \% \\
32.1 \% \\
29.6 \%\end{array}$ & $\begin{array}{r}0.0 \% \\
27.8 \% \\
31.3 \% \\
24.1 \%\end{array}$ & $\begin{array}{r}0.0 \% \\
31.2 \% \\
36.6 \% \\
46.3 \%\end{array}$ \\
\hline \multicolumn{4}{|l|}{ Sex of Respondent } \\
\hline $\begin{array}{lr}\text { - Male } & (n=243) \\
\text { - Female } & (n=99)\end{array}$ & $\begin{array}{l}38.3 \% \\
31.3 \%\end{array}$ & $\begin{array}{l}25.9 \% \\
34.3 \%\end{array}$ & $\begin{array}{l}35.8 \% \\
34.3 \%\end{array}$ \\
\hline \multicolumn{4}{|l|}{ Education of Respondent } \\
\hline $\begin{array}{l}\text { - Less than high school } \\
\text { graduate } \quad(n=23) \\
\text { - High school graduate } \\
\text { through some } \\
\text { college } \quad(n=175) \\
\text { - College degree or } \quad(n=138) \\
\text { more } \quad(n)\end{array}$ & $40.6 \%$ & $26.8 \%$ & $32.6 \%$ \\
\hline \multicolumn{4}{|l|}{ Total Household Income } \\
\hline $\begin{array}{l}\text { - Less than } \$ 16,000 \quad(n=47) \\
\text { - } \$ 16,000-\$ 34,999 \quad(n=139) \\
\text { - } \$ 35,000 \text { or more } \quad(n=130)\end{array}$ & $\begin{array}{l}23.4 \% \\
33.1 \% \\
49.1 \%\end{array}$ & $\begin{array}{l}31.9 \% \\
30.2 \% \\
37.4 \%\end{array}$ & $\begin{array}{l}44.7 \% \\
36.7 \% \\
31.5 \%\end{array}$ \\
\hline
\end{tabular}

(a) "Some college" includes post high school vocational training.

income they allocated to different categories of goods and services.

Table 4.24 shows the different categories with their associated descriptive statistics (mean, standard deviation, median, minimum value, and maximurn value). When looking at mean percentages of allocation, housing was the largest expenditure with an average value of $20.2 \%$ of household income. This was closely followed by food with an average expenditure of $17.6 \%$. What is most interesting in terins of this report is that household energy expenses were reported as the third largest expense for the ELCAP dwellings with an average allocation of $11.8 \%$ of their total household income. 
TABLE 4.21. The 86R0S Demographic Information by Respondents' Attitudes Toward the Statement "People have a right to use as much energy as they want and can pay for"

\begin{tabular}{|c|c|c|c|}
\hline & $\begin{array}{c}\text { Strongly Disagree } \\
\text { or Disagree } \\
\end{array}$ & Neutral & $\begin{array}{l}\text { Strongly Agree } \\
\text { or Agree }\end{array}$ \\
\hline \multicolumn{4}{|l|}{ Age of Respondent } \\
\hline $\begin{array}{lr}\text { - } 25 \text { years or less } & (n=2) \\
\text { - } 26-45 \text { years } & (n=175) \\
\text { - } 46-65 \text { years } & (n=115) \\
\text { - 66 years or more } & (n=57)\end{array}$ & $\begin{array}{l}50.0 \% \\
54.3 \% \\
61.7 \% \\
45.6 \%\end{array}$ & $\begin{array}{l}50.0 \% \\
22.3 \% \\
20.9 \% \\
14.0 \%\end{array}$ & $\begin{array}{l}D .0 \% \\
23.4 \% \\
17.4 \% \\
40.4 \%\end{array}$ \\
\hline \multicolumn{4}{|l|}{ Sex of Respondent } \\
\hline $\begin{array}{ll}\text { - Male } & (n=249) \\
\text { - Female } & (n=101)\end{array}$ & $\begin{array}{l}52.2 \% \\
63.4 \%\end{array}$ & $\begin{array}{l}22.5 \% \\
15.8 \%\end{array}$ & $\begin{array}{l}25.3 \% \\
20.8 \%\end{array}$ \\
\hline \multicolumn{4}{|l|}{ Education of Respondent } \\
\hline $\begin{array}{l}\text { - Less than high school } \\
\text { graduate } \quad(n=26) \\
\text { - High school graduate } \\
\text { through some } \\
\text { college }(a) \quad(n=178) \\
\text { - College degree or } \\
\text { more } \quad(n=140)\end{array}$ & $54.5 \%$ & $22.9 \%$ & $17.9 \%$ \\
\hline \multicolumn{4}{|l|}{ Total Household Income } \\
\hline $\begin{array}{l}\text { - Less than } \$ 16,000 \quad(n=48) \\
\text { - } \$ 16,000-\$ 34,999 \quad(n=143) \\
\text { - } \$ 35,000 \text { or more } \quad(n=132)\end{array}$ & $\begin{array}{l}41.7 \% \\
57.3 \% \\
60.6 \%\end{array}$ & $\begin{array}{l}18.8 \% \\
20.3 \% \\
22.0 \%\end{array}$ & $\begin{array}{l}39.6 \% \\
22.4 \% \\
17.4 \%\end{array}$ \\
\hline
\end{tabular}

(a) "Some college" includes post high school vocational training.

Table 4.25 illustrates the relationship between the reported allocation of total household income among expenditure categories and the level of household income. Reported actual dollar amount spent on each expenditure category can be roughly estimated by multiplying the mean percent allocated for a particular category by the income level. By doing this it is possible to see whether reported actual dollar amounts change for an expenditure category over household income levels. For example, even though the percent of income for household energy decreases by approximately $50 \%$ over the income levels, the estimated dollar amount spent remains relatively constant. 
TABLE 4.22. The 86ROS Demographic Information by Respondents' Attitudes Toward the Statement "The price I first pay for the appliance is more important to me than the energy savings"

Strongly Disagree or Disagree

Age of Respondent

- 25 years or less

- 26-45 years

- 46-65 years

- 66 years or more $\quad(n=58)$

Sex of Respondent

- Male

- Fenale

$(n=101)$

Education of Respondent

- Less than high school graduate

- High school graduate through some college ${ }^{(a)}$

- College degree or more
$100.0 \%$

$53.4 \%$

$60.9 \%$

$43.1 \%$

$55.8 \%$

$50.5 \%$
$63.0 \%$

$53.9 \%$

$54.6 \%$

$(n=141)$
Strongly Agree

Neutra1

$0.0 \%$

$26.1 \%$

$19.1 \%$

$27.6 \%$

$20.3 \%$

$33.7 \%$

$23.9 \%$

$15.8 \%$
$0.0 \%$

$20.5 \%$

$20.0 \%$

$29.3 \%$

Total Household Income

- Less than $\$ 16,000 \quad(n=49)$

- $\$ 16,000-\$ 34,999 \quad(n=144)$

- $\$ 35,000$ or more $(n=132)$

$14.8 \%$

$22.2 \%$

$27.0 \%$

$19.1 \%$

$22.0 \%$

$23.4 \%$

$51.0 \%$

$59.0 \%$

$22.5 \%$

$24.3 \%$

$53.0 \%$

$23.5 \%$

$26.5 \%$

$16.7 \%$

$23.5 \%$

(a) "Some college" includes post high school vocational training. 
TABLE 4.23. The 86R0S Demographic Information by Respondents' Attitudes Toward the Statement "To conserve enough energy to make a difference in my bills I would have to change my lifestyle"

Strongly Disagree

or Disagree

Age of Respondent

- 25 years or less

- 26-45 years

- 46-65 years

- 66 years or more $(n=58)$

Sex of Respondent

- Male

- Female

$(n=251)$

$(n=101)$

Education of Respondent

- Less than high school graduate

- High school graduate through spme college $(a) \quad(n=179)$

- College degree or more

$50.0 \%$

$41.5 \%$

$47.0 \%$

$25.9 \%$

$39.6 \%$

$29.6 \%$

$40.2 \%$

$45.0 \%$
$41.8 \%$

$25.9 \%$

$44.4 \%$

$24.6 \%$

$35.2 \%$

$18.6 \%$

$36.4 \%$

Total Household Income

- Less than $\$ 16,000 \quad(n=50)$

- \$16,000-\$34,999 ( $n=143)$

- $\$ 35,000$ or more $(n=132)$
$42.0 \%$

$41.3 \%$

$40.9 \%$
$20.0 \%$

$22.4 \%$

$22.7 \%$
$50.0 \%$

$34.7 \%$

$27.8 \%$

$58.6 \%$

(a) "Some college" includes post high school vocational training. 
TABLE 4.24. Reported Allocation of 1985 Tota1 Household Income $(n=268)$

\begin{tabular}{|c|c|c|c|c|c|}
\hline Expenditures & Mean & $\begin{array}{l}\text { Standard } \\
\text { Deviation }\end{array}$ & Median & $\begin{array}{c}\text { Minimum } \\
\text { Value }\end{array}$ & $\begin{array}{l}\text { Maximum } \\
\text { value }\end{array}$ \\
\hline Transportation & $7.7 \%$ & $7.3 \%$ & $5.6 \%$ & $0 \%$ & $40.0 \%$ \\
\hline Housing & $20.2 \%$ & $13.0 \%$ & $20.0 \%$ & $0 \%$ & $75.0 \%$ \\
\hline Household Durables & $3.9 \%$ & $4.2 \%$ & $2.0 \%$ & $0 \%$ & $20.0 \%$ \\
\hline Household Energy & $11.8 \%$ & $7.9 \%$ & $10.0 \%$ & $0 \%$ & $50.0 \%$ \\
\hline Food & $17.7 \%$ & $9.9 \%$ & $15.0 \%$ & $0 \%$ & $60.0 \%$ \\
\hline Clothing & $6.3 \%$ & $4.3 \%$ & $5.0 \%$ & $0 \%$ & $22.0 \%$ \\
\hline Recreation/Entertainment & $7.1 \%$ & $5.2 \%$ & $5.0 \%$ & $0 \%$ & $32.0 \%$ \\
\hline Medical & $5.8 \%$ & $5.4 \%$ & $5.0 \%$ & $0 \%$ & $32.0 \%$ \\
\hline Savings & $9.2 \%$ & $9.9 \%$ & $5.0 \%$ & $0 \%$ & $55.0 \%$ \\
\hline Other & $10.2 \%$ & $13.1 \%$ & $5.0 \%$ & $0 \%$ & $55.0 \%$ \\
\hline
\end{tabular}

TABLE 4.25. Reported Allocation of 1985 Total Household Income by Total Household Income

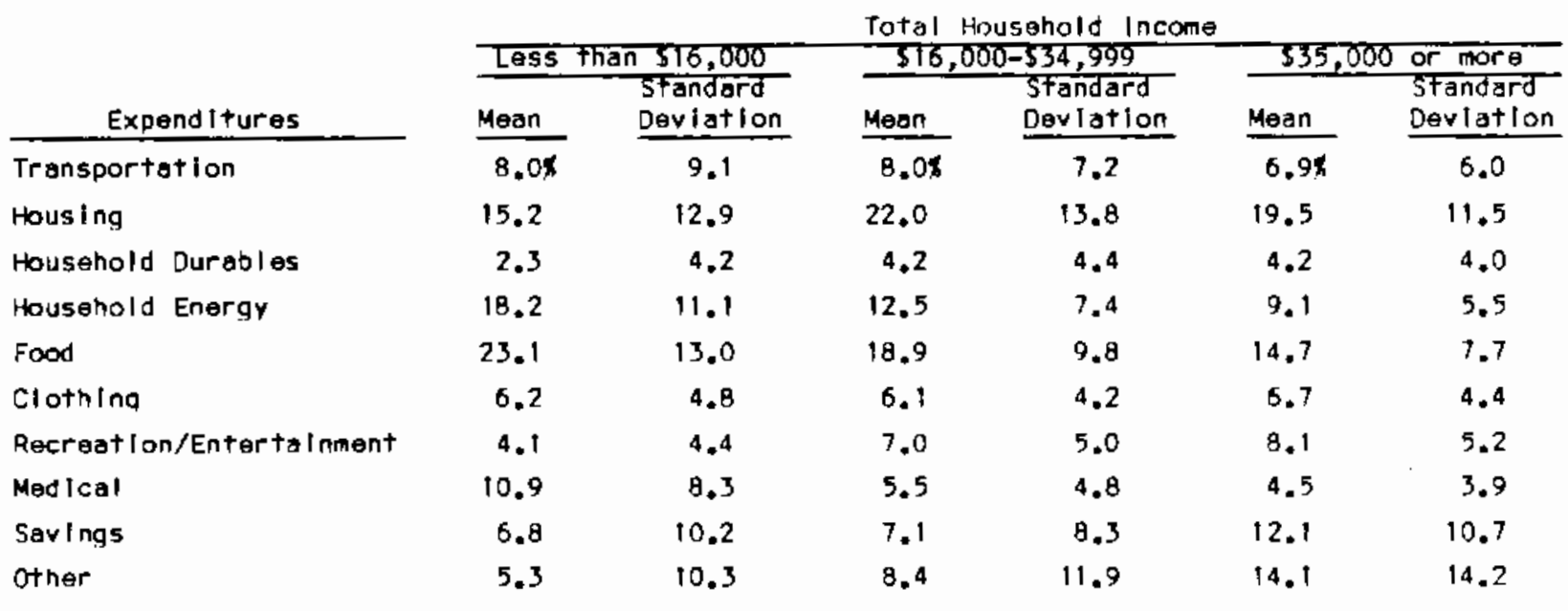


APPENDIX A

SURVEY INSTRUMENT 
Pacific Northwest Laboratory is currently in the process of updating their records on all the residents currontly participating in the ELCAP studies. As an ELCAP participant, they would appreciate you taking a moment of your time to fill out the enclosed survey and return it in the enclosed self-addressed stamped envelope. All tnformation from this survey will be kept strictly confidential.

Q-1. Please circle the number of the statement that best describes how you feel about the energy efficiency of your home?

1. My home is about as energy efficient as it can be

2. A littie improvement can be made

3. Moderate improvement can be made

4. A lot of improvement can be made

5. Do not know

Q-2. What temperature did you keep the main occupied space of your home when people were at home and awake during the last heating season?

$$
\text { Degrees Fahrenheit }
$$

Q-3. Are there any rooms in your home that are not heated during most months when heating is necessary? (Please check the appropriate blank below.)

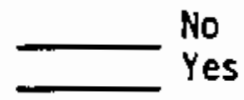

If yes, please indicate how many of each of the following rooms are not heated: (Put your answers in the appropriate bianks below.)

\begin{tabular}{l} 
Bedrooms \\
Bathrooms \\
Den, Study, Library, Sewing Room \\
Dining Room \\
Family Room or Recreation Rooms \\
Kitchens with eating areas \\
\hline Kitchens without eating areas \\
Living Room \\
Other smail room (80 sq. $\mathrm{ft}$. or less) \\
Other large room (more than $\mathrm{BO}$ sq. $\mathrm{ft}$ )
\end{tabular}

Q-4. In order to help us better understand how you use energy in your home, would you please tell us how many times, since May 1, 19B5, there have been periods of at least one week when you did not use any of your appliances, heating or cooling equipment, or any other large equipment, because you were away on vacation, on business, were hospitalized or for some other reason. (Put your answer in the appropriate blank below.) 
Q-5. On the average, how many times a day are pets let out of the heated part of your hone? (Please put your answer in the appropriate blank below.)

There are ne house pets No pets are let out of the home on a daily basis

Pets are let out 1-4 times per day

Pets are let oll 5-10 times per day

Pets are let out 11 times or more per day

- Pets go out through a pet door or pet crawlspace

Q-6. For each of the following statements, please indicate how strongly you agree or disagree with the statement. (Circle the number that best describes your feelings.)

Strongly Agree

(a) In the winter. I find it difficult to be comfortable when the temperature in my home is $68 \mathrm{~F}$ or less ..................

(b) Reducing the temperature of the water heater from $140 \mathrm{~F}$ to $120 \mathrm{~F}$ saves enough energy to make it worth doing.

(c) The main reason to conserve energy is to

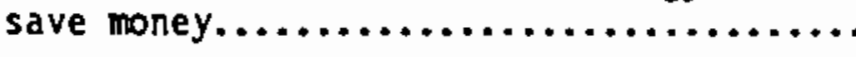

(d) During the winter, when no one will be home for 2 hours or more, turning the

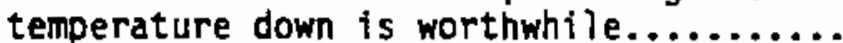

(e) It's hard for me to get around to making my home more energy efficient............

(f) People have a right to use as much energy as they want and can pay for.............

(g) The price I first pay for the appliance is more important to me than the energy savings............................

(h) To conserve enough energy to make a difference in my bilis I would have to change my lifestyle.
Strongly

Disagree

$\begin{array}{lllll}1 & 2 & 3 & 4 & 5\end{array}$

$\begin{array}{lllll}1 & 2 & 3 & 4 & 5\end{array}$

$\begin{array}{lllll}1 & 2 & 3 & 4 & 5\end{array}$

$\begin{array}{lllll}1 & 2 & 3 & 4 & 5\end{array}$

$\begin{array}{lllll}1 & 2 & 3 & 4 & 5\end{array}$

$\begin{array}{lllll}1 & 2 & 3 & 4 & 5\end{array}$

$\begin{array}{lllll}1 & 2 & 3 & 4 & 5\end{array}$

$\begin{array}{lllll}1 & 2 & 3 & 4 & 5\end{array}$


Q-7. How many people live in your household, fncluding yourself?

(Please count all members who lived in your household for at leasi 6 of the past 12 months whether or not they are related to you.)

Number of people under 6 years old in household Number of people 6 through 17 years old in household Number of people 18 through 65 years old in household Number of people over 66 years old in household

Q-8. What is your age and the age of the second householder? (Please check the appropriate blanks below.)

Respondent

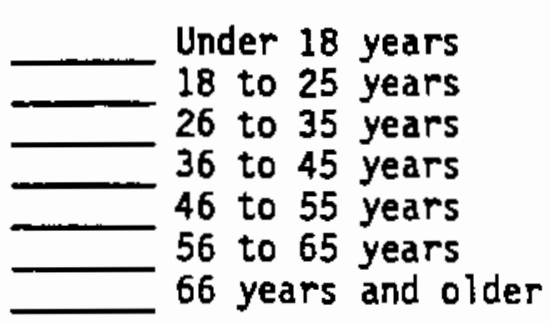

Second Householder

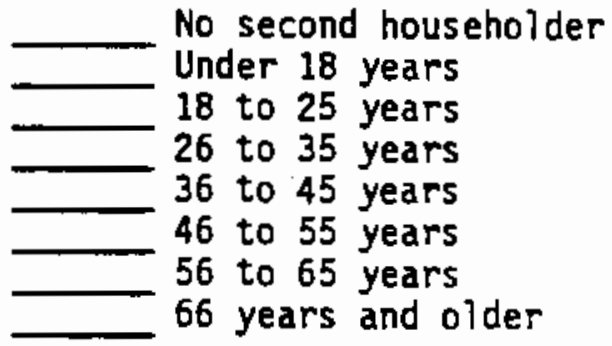

Q-9. What is your sex and the sex of the second householder? (Please check the appropriate blanks below.)

Respondent

Male Female
Second Householder

No second householder
Male
Female

Q-10. Are you and the second householder employed full-time?

(Please check the appropriate blanks below.)

Respondent

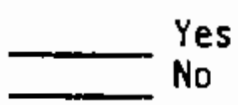

Second Householder No second househoider Yes 
Q-11. What is the last grade or year of school completed by yourself and the second householder? (Please check the appropriate blanks below.)

Respondent

Never attended

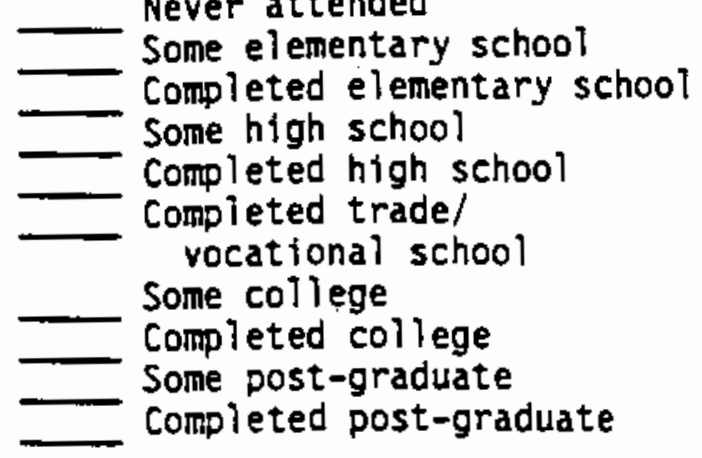

Second Householder

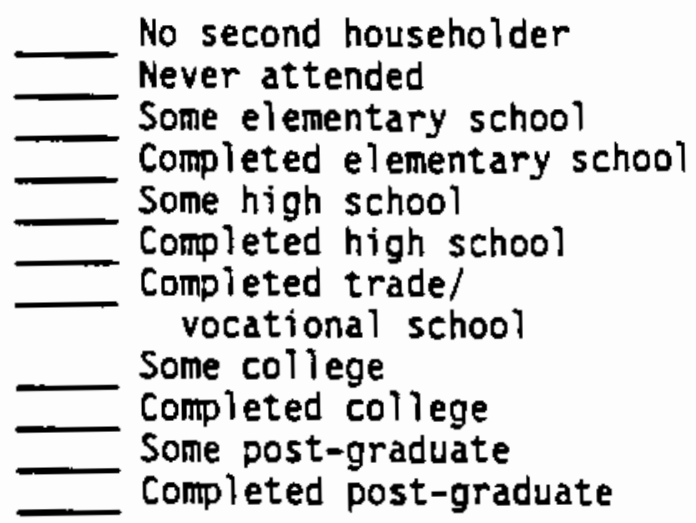

Q-12. Please circle the number which best describes the total combined income before taxes for your household for 1985. (Inciude money from social security, welfare, unemployment, bonds, dividends, lotteries, etc.)

1. Under $\$ 8,000$

2. $\$ 8,000$ to $\$ 15,999$

3. $\$ 16,000$ to $\$ 24,999$

4. $\$ 25,000$ to $\$ 34,999$

5. $\$ 35,000$ to $\$ 59,999$

6. $\$ 60,000$ and over

7. Do not know

Q-13. Please estimate what percent of your total combined income for 1985 was a? located to each of the categories listed below. (The estimates should sum to $100 \%$ )

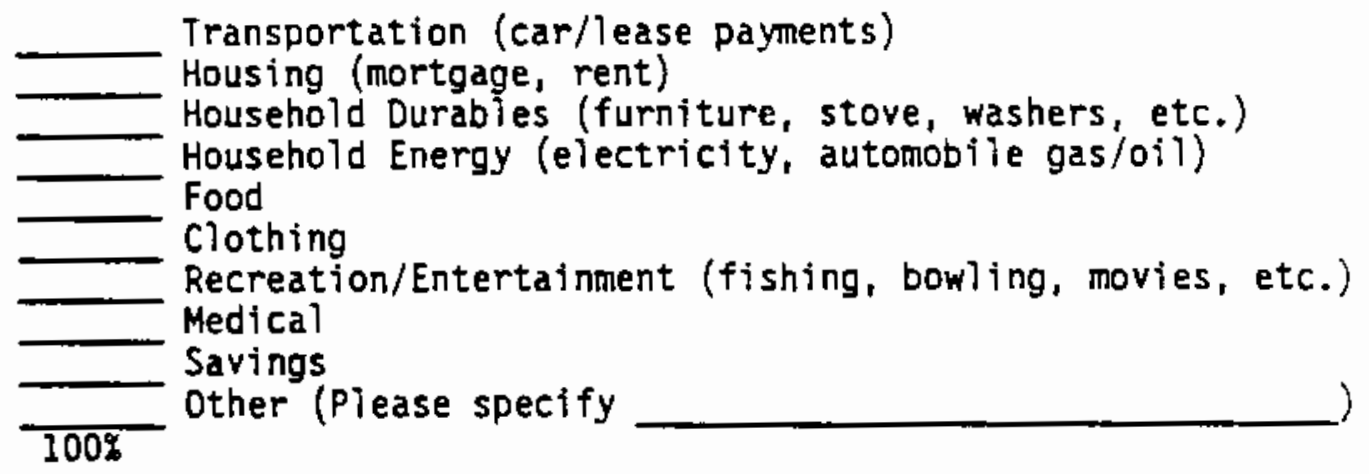

Thank you very much for taking time to fill out this survey: 
APPENDIX B

SURVEY FREQUENCIES 
$S \Lambda S$

RESB 6 EATISTICS: CUESIIOH 1

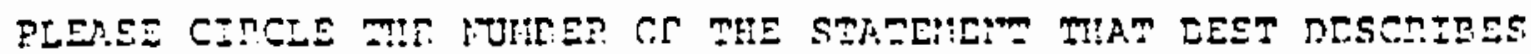
HOH YOU EEEL A.TOUT FIE EUTEGY EFFICIENCY OF YOUT. HOHE?

\begin{tabular}{|c|c|c|c|c|c|}
\hline & rosa $6{ }^{+}$ & ERE@UE!:CY & DRгCE:"' & $\begin{array}{l}\text { CHUULRTIVE } \\
\text { FREATEUCY }\end{array}$ & 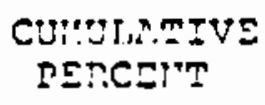 \\
\hline 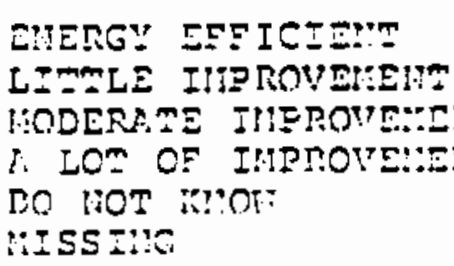 & m & $\begin{array}{r}57 \\
156 \\
100 \\
32 \\
4 \\
7\end{array}$ & $\begin{array}{l}16.0 \\
13.8 \\
23.1 \\
5.0 \\
1.1 \\
2.0\end{array}$ & $\begin{array}{r}37 \\
213 \\
313 \\
365 \\
348 \\
356\end{array}$ & $\begin{array}{r}16.0 \\
59.8 \\
07.0 \\
26.0 \\
58.0 \\
100.0\end{array}$ \\
\hline
\end{tabular}

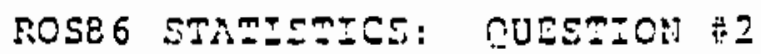

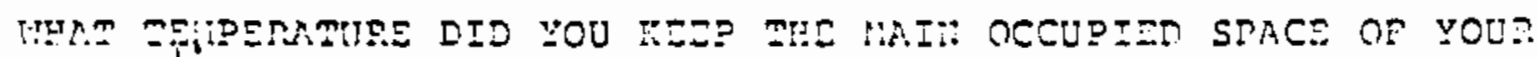

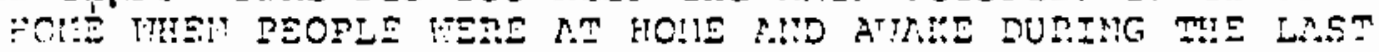
FEATIIS, SENSOLT?

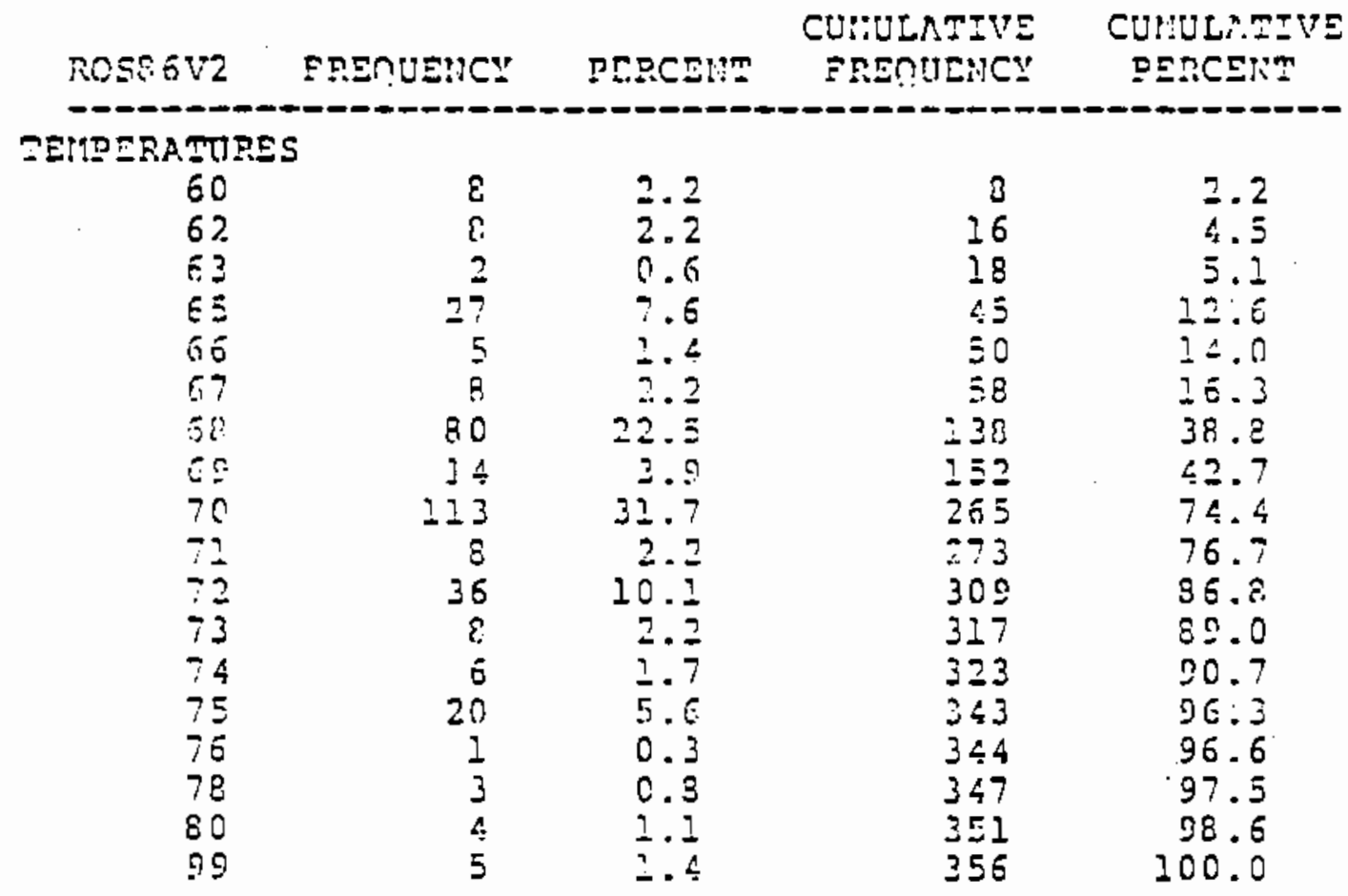




\section{SAS}

ROS86 STNMISTICS: OUESTION $\div 3$

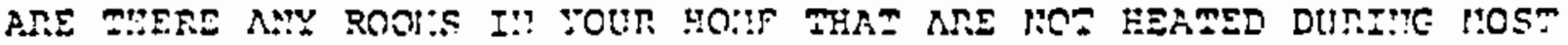

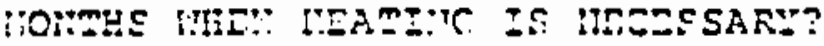

\begin{tabular}{|c|c|c|c|c|c|}
\hline & rosinges & PESOUE:'CE & PEsctit? & 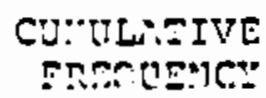 & 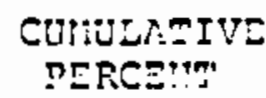 \\
\hline $\begin{array}{l}\text { ro } \\
\text { YES } \\
\text { Mesmath }\end{array}$ & $\begin{array}{l}0 \\
1 \\
?\end{array}$ & $\begin{array}{r}150 \\
205 \\
1\end{array}$ & $\begin{array}{r}42.1 \\
57.5 \\
0.3\end{array}$ & $\begin{array}{l}150 \\
255 \\
350\end{array}$ & $\begin{array}{r}42.1 \\
29.7 \\
100.0\end{array}$ \\
\hline
\end{tabular}

\section{ROS?G STATISTICS: CUESTIOH \#}

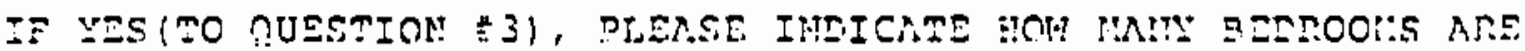
IIOT HEATES?

\begin{tabular}{|c|c|c|c|c|c|}
\hline & $20536 \mathrm{VA}$, & ERsกUE!cy & PERCE:"R & $\begin{array}{l}\text { COPMLATIVE } \\
\text { EPEREIETCS }\end{array}$ & $\begin{array}{l}\text { CU::ULA.TIVE } \\
\text { DERCENT }\end{array}$ \\
\hline 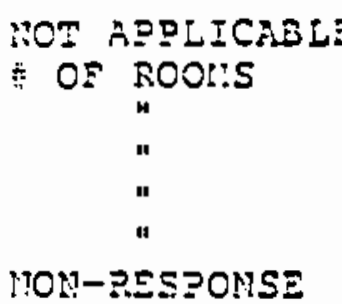 & $\begin{array}{r}-97 \\
0 \\
1 \\
2 \\
3 \\
4 \\
0\end{array}$ & $\begin{array}{r}151 \\
40 \\
53 \\
69 \\
10 \\
2 \\
31\end{array}$ & $\begin{array}{l}22.4 \\
11.2 \\
14.5 \\
19.4 \\
2.8 \\
0.6 \\
8.7\end{array}$ & $\begin{array}{l}151 \\
191 \\
244 \\
313 \\
323 \\
325 \\
356\end{array}$ & $\begin{array}{r}.2 .4 \\
53.7 \\
68.5 \\
37.9 \\
90.7 \\
91.3 \\
100.0\end{array}$ \\
\hline
\end{tabular}

ROSE 6 STATISTICS: QUESTIOI $\frac{\pi}{\pi} 3 R$

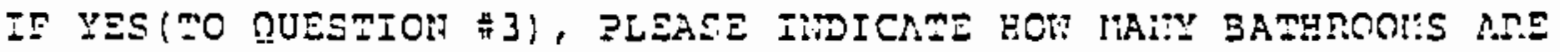
nOT HUI:D?

\begin{tabular}{|c|c|c|c|c|c|}
\hline & RCSAGV & इREกUE::C' & ?ESCEI4 & $\begin{array}{l}\text { CU:TULATIVE } \\
\text { ERECUEHCY }\end{array}$ & $\begin{array}{l}\text { CUIUUATIVE } \\
\text { PERCEYM }\end{array}$ \\
\hline $\begin{array}{l}\text { NOF REPLICALLE } \\
\text { " OF ROO:S } \\
" \\
\text { MOH-IESPONSE }\end{array}$ & $\begin{array}{r}-97 \\
0 \\
\frac{1}{2} \\
0\end{array}$ & $\begin{array}{r}151 \\
132 \\
47 \\
10 \\
16\end{array}$ & $\begin{array}{r}42.4 \\
37.1 \\
13.2 \\
2.8 \\
4.5\end{array}$ & $\begin{array}{l}151 \\
283 \\
330 \\
340 \\
356\end{array}$ & $\begin{array}{r}42.4 \\
70.5 \\
22.7 \\
95.5 \\
100.0\end{array}$ \\
\hline
\end{tabular}

ROSS 6 SEATISITSS: QUESTION $\# 3 C$

IF VES(TO QUESEION $\$ 3)$, PLEASE INDICATE FOH HANY DEMS, STUDYS, LIERARYS OR SETIING ROO:SS ARE NOT HEATED?

\begin{tabular}{|c|c|c|c|c|c|}
\hline $\mathrm{RO}$ & $6: 6$ & ERECUUNTCY & PERCENT & $\begin{array}{l}\text { CUNULARIYE } \\
\text { FrequENCY }\end{array}$ & $\begin{array}{l}\text { CUMULAATTVE } \\
\text { PERCEHT }\end{array}$ \\
\hline 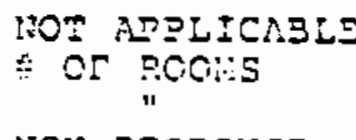 & $\begin{array}{r}-\varrho 7 \\
0 \\
1\end{array}$ & $\begin{array}{r}151 \\
175 \\
17\end{array}$ & $\begin{array}{r}42.4 \\
49.2 \\
4.8\end{array}$ & $\begin{array}{l}151 \\
320 \\
343\end{array}$ & $\begin{array}{l}42.4 \\
51.6 \\
0.3\end{array}$ \\
\hline I:OH-E:Ecso:3a & 5 & 13 & 3.7 & 255 & 100.0 \\
\hline
\end{tabular}


sis

KOS8 STA.TERISE: OUESTION 40

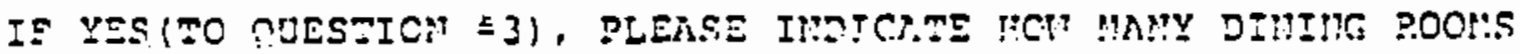
ARE $\mathrm{NOT}$ RESTES?

\begin{tabular}{|c|c|c|c|c|c|}
\hline & n.sรง 647 & ERRח(Z)! & SERCEIT & 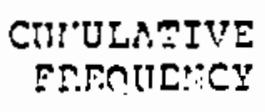 & $\begin{array}{l}\text { CUUULIMIVS } \\
\text { PERCEYM }\end{array}$ \\
\hline 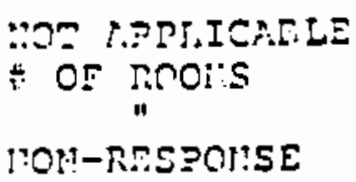 & $\begin{array}{r}-57 \\
0 \\
1 \\
0\end{array}$ & $\begin{array}{r}151 \\
195 \\
8 \\
6\end{array}$ & $\begin{array}{r}5.2 .4 \\
54.6 \\
3.1 \\
1.7\end{array}$ & $\begin{array}{l}151 \\
346 \\
350 \\
356\end{array}$ & $\begin{array}{r}42.4 \\
07.2 \\
98.3 \\
100.0\end{array}$ \\
\hline
\end{tabular}

ROSSG STRTSTICS: OUERTION $42 \mathrm{E}$

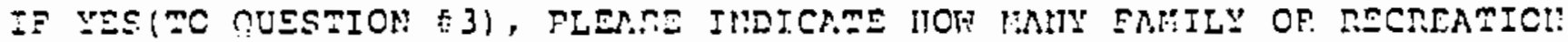
ROO:S ARE WOT MEATED?

\begin{tabular}{|c|c|c|c|c|c|}
\hline & rossovis & ERENUEICY & PERCEYT & $\begin{array}{l}\text { CUIULATIVE } \\
\text { FRENUE:?CY }\end{array}$ & $\begin{array}{c}\text { CUIJULATIV } \\
\text { PERCENT }\end{array}$ \\
\hline $\begin{array}{l}\text { :CM NPQLICNELE } \\
\# \text { OF ROO!:S } \\
n \\
\text { ?OM-PESPONSE }\end{array}$ & $\begin{array}{r}-97 \\
0 \\
1 \\
9\end{array}$ & $\begin{array}{r}151 \\
123 \\
12 \\
5\end{array}$ & $\begin{array}{r}42.4 \\
-2.3 \\
3.4 \\
1.4\end{array}$ & $\begin{array}{l}151 \\
339 \\
351 \\
356\end{array}$ & $\begin{array}{r}42.4 \\
95.2 \\
98.6 \\
100.0\end{array}$ \\
\hline
\end{tabular}

ROSPE STARISTICS: CUESTION

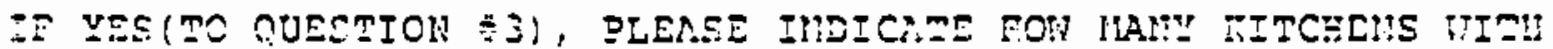
ENTIIC AREAS ARE MOT REATED?

\begin{tabular}{|c|c|c|c|c|c|}
\hline & rosasyo & ERECUEMCI & DERCE!H & $\begin{array}{l}\text { CUIULATIVE } \\
\text { EREOUEYCY }\end{array}$ & $\begin{array}{l}\text { CURULAEIVS } \\
\text { PEACEIM }\end{array}$ \\
\hline $\begin{array}{l}\text { NCM r.PPLICAELE } \\
\text { OF RCOIS } \\
\text { nOH-EESPONSE }\end{array}$ & $\begin{array}{r}-97 \\
0 \\
1 \\
0\end{array}$ & $\begin{array}{r}151 \\
158 \\
2 \\
5\end{array}$ & $\begin{array}{r}42.4 \\
53.6 \\
0.6 \\
1.4\end{array}$ & $\begin{array}{l}151 \\
349 \\
351 \\
355\end{array}$ & $\begin{array}{r}42.4 \\
58.0 \\
58.6 \\
100.0\end{array}$ \\
\hline
\end{tabular}

ROS8 6 STnTISTICS: QUESTION *3G

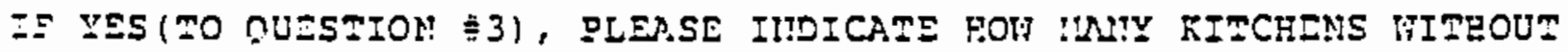
EATING RESAS ARE NOT HEATED?

\begin{tabular}{|c|c|c|c|c|c|}
\hline & F.058 $6 \mathrm{VIO}$ & ESECQRENTY & PERCEYT & $\begin{array}{l}\text { CUMULATIVE } \\
\text { FraCUENCV }\end{array}$ & $\begin{array}{l}\text { COLULATIVE } \\
\text { PERCEIT }\end{array}$ \\
\hline 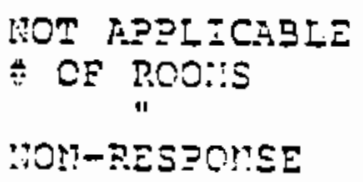 & $\begin{array}{r}-57 \\
0 \\
1 \\
9\end{array}$ & $\begin{array}{r}151 \\
197 \\
3 \\
5\end{array}$ & $\begin{array}{r}42.4 \\
55.3 \\
0.8 \\
1.4\end{array}$ & $\begin{array}{l}151 \\
348 \\
351 \\
356\end{array}$ & $\begin{array}{r}42.4 \\
97.8 \\
98.6 \\
100.0\end{array}$ \\
\hline
\end{tabular}




\section{SAS}

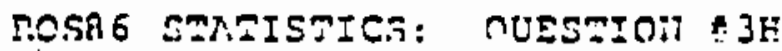

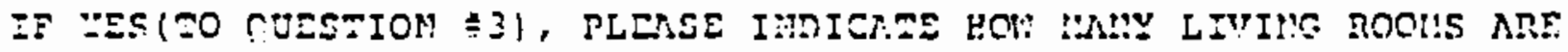
ICT HEATED?

\begin{tabular}{|c|c|c|c|c|c|}
\hline & תcsh 6 :11 & E SEAU1E!C: & SERCE:! & 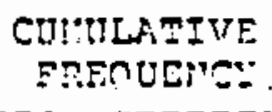 & $\begin{array}{c}\text { CUH!ULATIVE } \\
\text { PESCOI!T }\end{array}$ \\
\hline 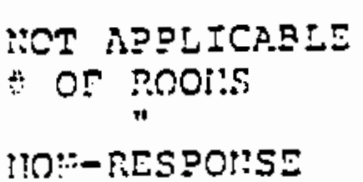 & $\begin{array}{r}-27 \\
0 \\
1 \\
5\end{array}$ & $\begin{array}{r}151 \\
197 \\
4 \\
6\end{array}$ & $\begin{array}{r}42 \cdot 4 \\
55 \cdot 3 \\
\frac{1}{1} \cdot \frac{1}{1}\end{array}$ & $\begin{array}{l}151 \\
340 \\
352 \\
356\end{array}$ & $\begin{array}{r}4=.4 \\
97.3 \\
98.9 \\
100.0\end{array}$ \\
\hline
\end{tabular}

ROSB6 STATISTICS: CUESTON

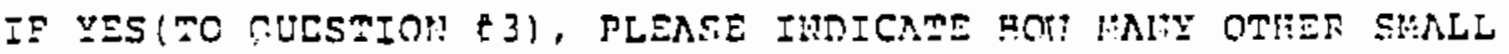
ROOHS ARE VOT LEATED?

\begin{tabular}{|c|c|c|c|c|c|}
\hline & $\operatorname{sosat} 6 \mathrm{vI} 2$ & EREOUE:CY & 프도: & $\begin{array}{l}\text { COUULA.EIVE } \\
\text { EREAUENCY }\end{array}$ & 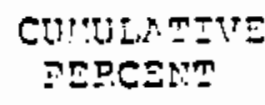 \\
\hline 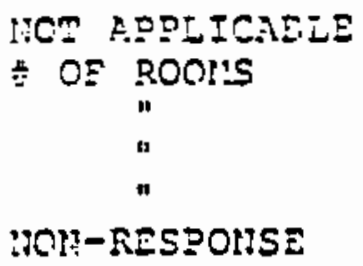 & $\begin{array}{r}-97 \\
0 \\
1 \\
2 \\
3 \\
9\end{array}$ & $\begin{array}{r}151 \\
152 \\
27 \\
7 \\
1 \\
18\end{array}$ & $\begin{array}{r}42.4 \\
42.7 \\
7.6 \\
2.0 \\
0.3 \\
5.1\end{array}$ & $\begin{array}{l}151 \\
303 \\
330 \\
337 \\
238 \\
356\end{array}$ & $\begin{array}{r}42.4 \\
85.1 \\
92.7 \\
94.7 \\
94.9 \\
100.0\end{array}$ \\
\hline
\end{tabular}

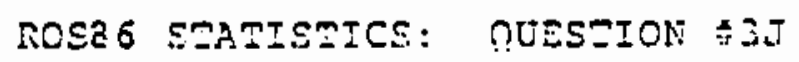

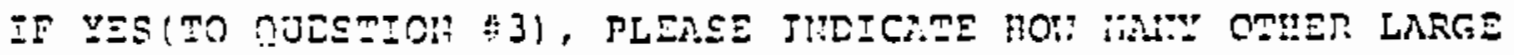
ROO:S RRE 1\%OT HEATES?

\begin{tabular}{|c|c|c|c|c|c|}
\hline & $30.526 \div 13$ & EREกUE:C: & PESCE:" & $\begin{array}{l}\text { CU:UULATIYL } \\
\text { EREQUEHCY }\end{array}$ & $\begin{array}{l}\text { CUIU LATIVE } \\
\text { PERCEMS }\end{array}$ \\
\hline $\begin{array}{l}\text { IOT APPLICAELE } \\
\text { OE POCIS } \\
" 1 \\
\text { MON-RESPOHSE }\end{array}$ & $\begin{array}{r}-97 \\
0 \\
1 \\
2 \\
9\end{array}$ & $\begin{array}{r}151 \\
174 \\
34 \\
1 \\
16\end{array}$ & $\begin{array}{r}42.4 \\
43.9 \\
3.9 \\
0.3 \\
4.5\end{array}$ & $\begin{array}{l}151 \\
325 \\
339 \\
340 \\
356\end{array}$ & $\begin{array}{r}42.4 \\
91.3 \\
95.2 \\
55.5 \\
100.0\end{array}$ \\
\hline
\end{tabular}




\section{Sis}

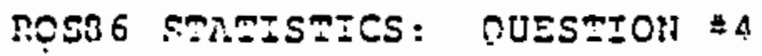

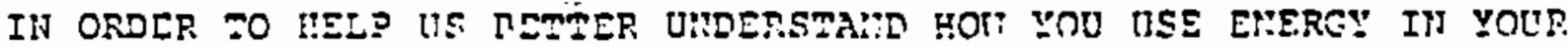
HOI:E, HOULD YOU PLEASE TELL US HOY HAYY TIIES, SIMCE MAY 2,1985 ,

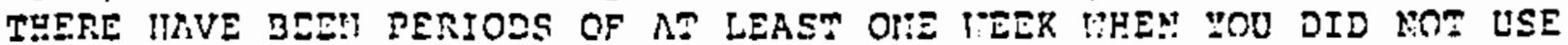

nity OF YOUS ADDLINICES, HERTIYG OP COOL

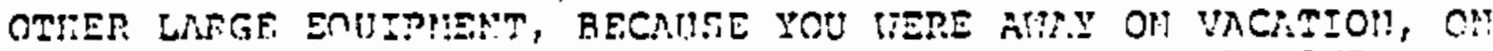

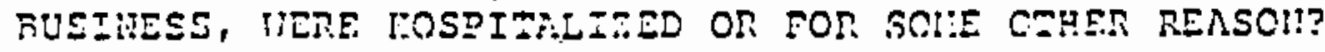

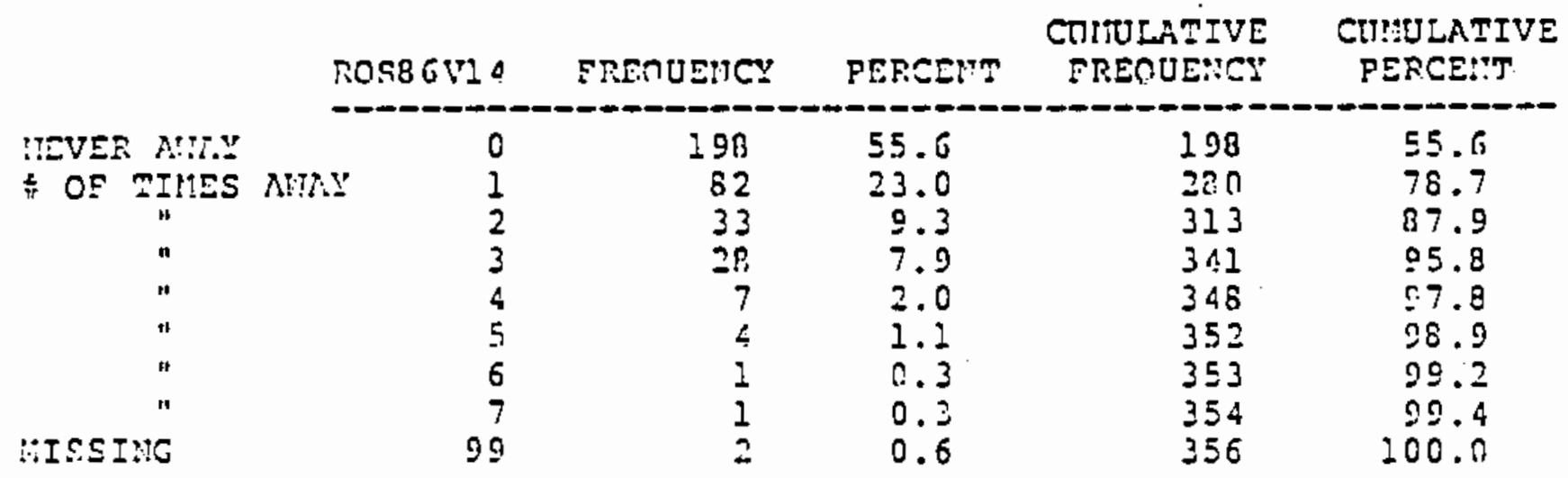

RoS86 STAEISTICS: CUESTION 군

ON THE RVERAGE, EOT IYANY TIIIES $\Lambda$ DAY ARE PEMS LET OUT OF THE HEATSD PART OF YOUR HOHE?

\begin{tabular}{|c|c|c|c|c|c|}
\hline & Ros86ry 5 & FR.EกUETSY & PERCEIT & $\begin{array}{l}\text { CUHULATIVE } \\
\text { EREOUETCI }\end{array}$ & $\begin{array}{c}\text { CUIHUATIVE } \\
\text { DERCETT }\end{array}$ \\
\hline 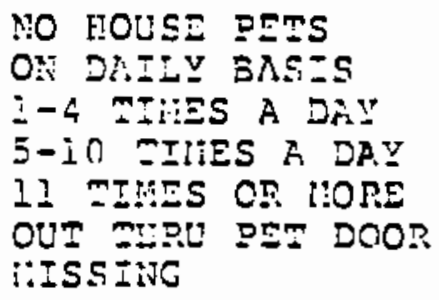 & $\begin{array}{l}1 \\
2 \\
3 \\
4 \\
5 \\
6 \\
5\end{array}$ & $\begin{array}{r}148 \\
27 \\
200 \\
67 \\
25 \\
6 \\
3\end{array}$ & $\begin{array}{r}41.6 \\
4.8 \\
20.1 \\
18.6 \\
4.2 \\
1.7 \\
0.0\end{array}$ & $\begin{array}{l}148 \\
165 \\
265 \\
332 \\
347 \\
353 \\
356\end{array}$ & $\begin{array}{r}41.6 \\
46.3 \\
74.4 \\
93.3 \\
97.5 \\
99.2 \\
100.0\end{array}$ \\
\hline
\end{tabular}

IOSB 6 STATISMICS: CUSSTION

IN THE IPIATER, I EIIT IT DIFFICULT TO BE COYEORTABLE HHEN TRE TEMPERATURE IN HY HOME IS OH $F$ OR LESS.

\begin{tabular}{|c|c|c|c|c|c|c|}
\hline & & ross $6 \mathrm{VI} 6$ & FREOUUEYCY & PERCENTT & $\begin{array}{l}\text { COMULATIVE } \\
\text { FREOUENCV }\end{array}$ & $\begin{array}{c}\text { CUIDLATIVE } \\
\text { DERCENT }\end{array}$ \\
\hline $\begin{array}{l}\text { SHRONGLY } \\
\text { AEREE } \\
\text { MEUTRAE } \\
\text { DISRGREE } \\
\text { STRONGLY } \\
\text { YISSING }\end{array}$ & $\begin{array}{l}\text { AGRES } \\
\text { DISAGRE: }\end{array}$ & $\begin{array}{l}1 \\
2 \\
3 \\
4 \\
5 \\
2\end{array}$ & $\begin{array}{r}109 \\
79 \\
69 \\
56 \\
41 \\
2\end{array}$ & $\begin{array}{l}30.6 \\
22.2 \\
12.4 \\
15.7 \\
11.5 \\
0.6\end{array}$ & $\begin{array}{l}109 \\
188 \\
257 \\
313 \\
354 \\
356\end{array}$ & $\begin{array}{r}30.6 \\
52.6 \\
72.2 \\
87.9 \\
99.4 \\
100.0\end{array}$ \\
\hline
\end{tabular}


Siss

ROSO6 STATISTICS: กUESION EGR

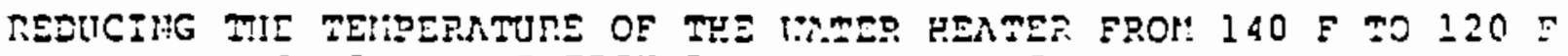
SAVES E:OUG: ENERGY TO I:AIE IE HORTH DOING.

\begin{tabular}{|c|c|c|c|c|c|c|}
\hline & & $\operatorname{xcs} 86417$ & TRECUENCY & PERCE:T' & 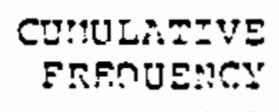 & $\begin{array}{l}\text { CUIULATEVE } \\
\text { PERCEY: }\end{array}$ \\
\hline $\begin{array}{l}\text { STRONGLY } \\
\text { AGRES } \\
\text { IIEUTRAL } \\
\text { DISNGREE } \\
\text { STRONGLY } \\
\text { IIISSIIG }\end{array}$ & $\begin{array}{l}\text { AGREI } \\
\text { DISAGEEE }\end{array}$ & $\begin{array}{l}1 \\
2 \\
3 \\
4 \\
5 \\
9\end{array}$ & $\begin{array}{r}102 \\
86 \\
97 \\
34 \\
28 \\
9\end{array}$ & $\begin{array}{r}28.7 \\
24.2 \\
27.2 \\
9.6 \\
7.9 \\
2.5\end{array}$ & $\begin{array}{l}102 \\
188 \\
285 \\
310 \\
347 \\
356\end{array}$ & $\begin{array}{r}2.8 .7 \\
52.3 \\
80.1 \\
89.6 \\
57.5 \\
100.0\end{array}$ \\
\hline
\end{tabular}

ROS86 SATISTICS: nUESTION \#GC

THE HAIL REASON TO CONSERVE EMERGY IS TO SAVE rOHEY.

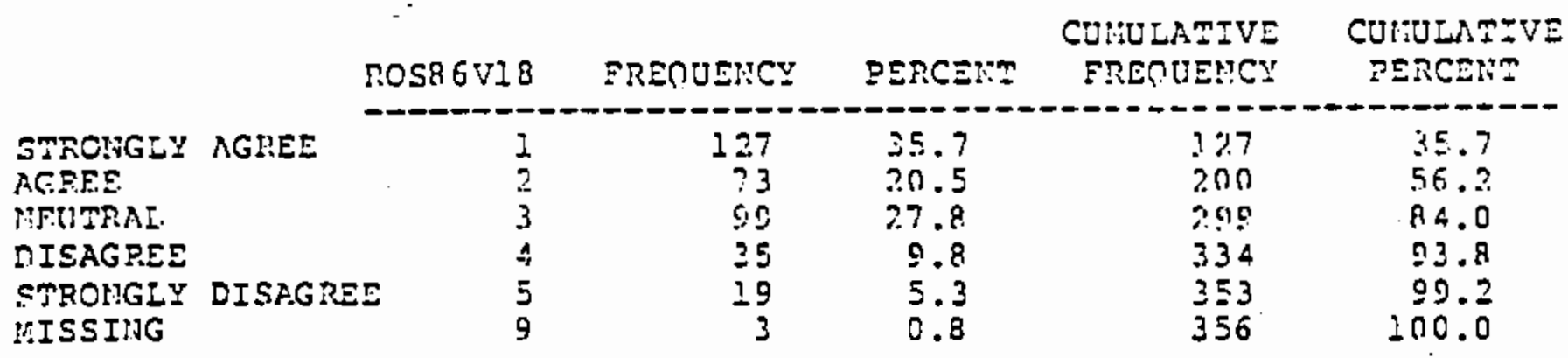

ROS8 6 STATISTICS: OUESTION $\# 60$

DURING THE TITTER, THEN MO OME TILI EE HOIE FOR 2 HOURS ON HORE,

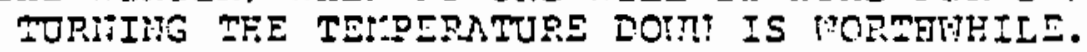

\begin{tabular}{|c|c|c|c|c|c|c|}
\hline & RO & & EF.ENUUETCY & PESCENT & $\begin{array}{l}\text { CUHULATIVE } \\
\text { FFEOUEHCY }\end{array}$ & $\begin{array}{l}\text { CUMULAFIVE } \\
\text { PERCEITT }\end{array}$ \\
\hline $\begin{array}{l}\text { STROIGLY } \\
\text { AGREE } \\
\text { WEUTRAL } \\
\text { DISFERES } \\
\text { STRONGIY } \\
\text { WISSIHG }\end{array}$ & DISAGREE & $\begin{array}{l}\frac{1}{2} \\
\frac{2}{3} \\
4 \\
5 \\
9\end{array}$ & $\begin{array}{r}121 \\
68 \\
59 \\
55 \\
47 \\
6\end{array}$ & $\begin{array}{l}34.0 \\
10.1 \\
16.6 \\
15.4 \\
13.2 \\
1.7\end{array}$ & $\begin{array}{l}121 \\
189 \\
248 \\
303 \\
350 \\
356\end{array}$ & $\begin{array}{r}34.0 \\
.52 .1 \\
69.7 \\
85.1 \\
98.3 \\
100.0\end{array}$ \\
\hline
\end{tabular}


SAS

RCSE 6 STATSSICS: DUESTION $\div 6 \mathrm{E}$

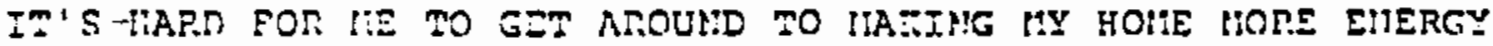
EFEICIE:T.

\begin{tabular}{|c|c|c|c|c|c|c|}
\hline & & $\operatorname{1os} 86 \sqrt{20}$ & FRENUENCY & PERCE:S & $\begin{array}{r}\text { CUHULATIVE } \\
\text { FRENUENG: }\end{array}$ & $\begin{array}{l}\text { CUMULATIVE } \\
\text { DERCEYT }\end{array}$ \\
\hline 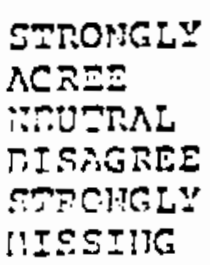 & $\begin{array}{l}\text { AGREE } \\
\text { TISARPE }\end{array}$ & $\begin{array}{l}\frac{1}{2} \\
\frac{2}{3} \\
4 \\
5 \\
5\end{array}$ & $\begin{array}{l}58 \\
63 \\
67 \\
65 \\
58 \\
12\end{array}$ & $\begin{array}{l}16.3 \\
17.7 \\
27.2 \\
1 . .3 \\
16.3 \\
3.4\end{array}$ & $\begin{array}{r}50 \\
121 \\
218 \\
286 \\
344 \\
356\end{array}$ & $\begin{array}{r}16.3 \\
34.0 \\
61.2 \\
80.3 \\
26.6 \\
200.0\end{array}$ \\
\hline
\end{tabular}

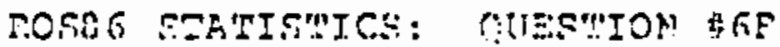

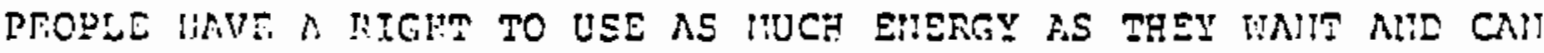
DNY FOR.

\begin{tabular}{|c|c|c|c|c|c|c|}
\hline & & $50536 V 21$ & EREOUEUC: & DERCENT & $\begin{array}{r}\text { CUIULA.TIV } \\
\text { EREOUE:YYY }\end{array}$ & $\begin{array}{l}\text { CURUULAEVE } \\
\text { PERCENT }\end{array}$ \\
\hline $\begin{array}{l}\text { STROITLY } \\
\text { NGREE } \\
\text { UEUTRAL } \\
\text { DISAGREE } \\
\text { SERONGIY } \\
\text { UISSING }\end{array}$ & $\begin{array}{l}\text { AGREE } \\
\text { DISIGRE }\end{array}$ & $\begin{array}{l}1 \\
2 \\
3 \\
4 \\
5 \\
0\end{array}$ & $\begin{array}{r}48 \\
36 \\
72 \\
80 \\
216 \\
4\end{array}$ & $\begin{array}{l}13.5 \\
10.1 \\
20.2 \\
22.5 \\
32.6 \\
1.1\end{array}$ & $\begin{array}{r}48 \\
84 \\
156 \\
236 \\
352 \\
356\end{array}$ & $\begin{array}{r}13.5 \\
23.6 \\
43.8 \\
66.3 \\
98.9 \\
200.0\end{array}$ \\
\hline
\end{tabular}

ROSB 5 STIRISMTCS: CUESTION

MHE PRICE I FIRSM PAY FOR MUE APPLIAIICE IS IUORE IMPORTAH TO LIE THAN THE ENERGY SAVIHGS.

\begin{tabular}{|c|c|c|c|c|c|c|}
\hline & & $\operatorname{ros} 85 \times 22$ & FRENUEHCY & PERCEITT & $\begin{array}{l}\text { CERULATIVE } \\
\text { ERENUENCY }\end{array}$ & $\begin{array}{l}\text { CUNULATIVE } \\
\text { OERCENT }\end{array}$ \\
\hline $\begin{array}{l}\text { STROHGLY } \\
\text { AGREE } \\
\text { INEUMRAL } \\
\text { DISAGREE } \\
\text { STRONGLY } \\
\text { IIISEING }\end{array}$ & DISAGR & $\begin{array}{l}1 \\
2 \\
3 \\
5 \\
5 \\
9\end{array}$ & $\begin{array}{r}18 \\
58 \\
85 \\
112 \\
81 \\
2\end{array}$ & $\begin{array}{r}5.1 \\
16.3 \\
23.0 \\
31.5 \\
22.8 \\
0.6\end{array}$ & $\begin{array}{r}78 \\
76 \\
161 \\
273 \\
354 \\
356\end{array}$ & $\begin{array}{r}5.1 \\
21.3 \\
45.2 \\
76.7 \\
99.4 \\
100.0\end{array}$ \\
\hline
\end{tabular}


SAS

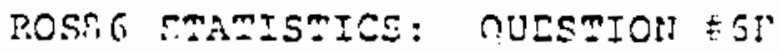

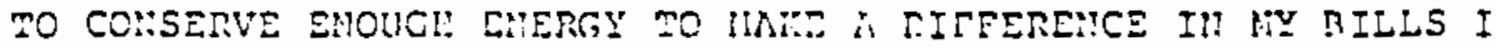
MOULD HAVE TO CHA.!!GE !Y LIEESTYE.

\begin{tabular}{|c|c|c|c|c|c|c|}
\hline & $\operatorname{sos} 8$ & & Ensntuster & DERCEN" & $\begin{array}{l}\text { CUIULAMIVE } \\
\text { FREAUEMCV }\end{array}$ & $\begin{array}{c}\text { CUHULAIIV } \\
\text { rERCEMm }\end{array}$ \\
\hline 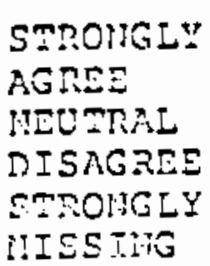 & $\begin{array}{l}\text { AGPEE } \\
\text { DISAGSEE }\end{array}$ & $\begin{array}{l}\frac{1}{2} \\
\frac{2}{3} \\
4 \\
5 \\
5\end{array}$ & $\begin{array}{r}58 \\
70 \\
80 \\
88 \\
58 \\
2\end{array}$ & $\begin{array}{r}16.3 \\
19.7 \\
22.5 \\
24.7 \\
16.3 \\
0.6\end{array}$ & $\begin{array}{l}58 \\
128 \\
208 \\
296 \\
354 \\
356\end{array}$ & $\begin{array}{r}16.3 \\
36.0 \\
58.4 \\
53.1 \\
29.4 \\
100.0\end{array}$ \\
\hline
\end{tabular}

SOSEG SAAISTICS: OUESTICH

HOI IMHY EEORLE LIVE IN YOUR HOUSEYOLD, UIDER 6 YanSS OLR,

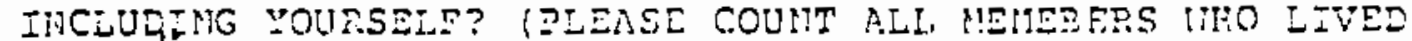
IN YOUR MOUSEKOLD FOS $T .$. LEASM 6 OF THE EAST 12 HOHMUS WEETES OR NOM TEEY $\triangle R E$ RELATEN TO YOU.।

\begin{tabular}{|c|c|c|c|c|}
\hline Roso6v2 4 & EREOUEICY & PERCE!? & $\begin{array}{l}\text { CUI:LLATIVE } \\
\text { FREOUENCY }\end{array}$ & $\begin{array}{l}\text { CUIULATIVE } \\
\text { PERCEN }\end{array}$ \\
\hline Count & & & & \\
\hline 0 & 277 & 77.3 & .77 & 77.8 \\
\hline 1 & 46 & \pm 2.9 & 323 & 80.7 \\
\hline 2 & 28 & 7.9 & 351 & 20.6 \\
\hline 3 & $\epsilon$ & 1.1 & 255 & 80.7 \\
\hline 4 & 1 & 0.3 & 356 & 100.0 \\
\hline
\end{tabular}

rose 6 SATISTICS: OUESTIOn \#7E

HOT ZMHY REOSLE LIVE IN YOUR HOUEEHCLD, 6 TIRU 17 YEARS OLD, EMCLUDIME YOURSELF? (ZLEASE COUMT ALI IEEUEBERS MHO LIVED

II YOUR HOUSEIOLD EOR A.T LEA.ST 6 OF TEE PAST 12 HONTHS

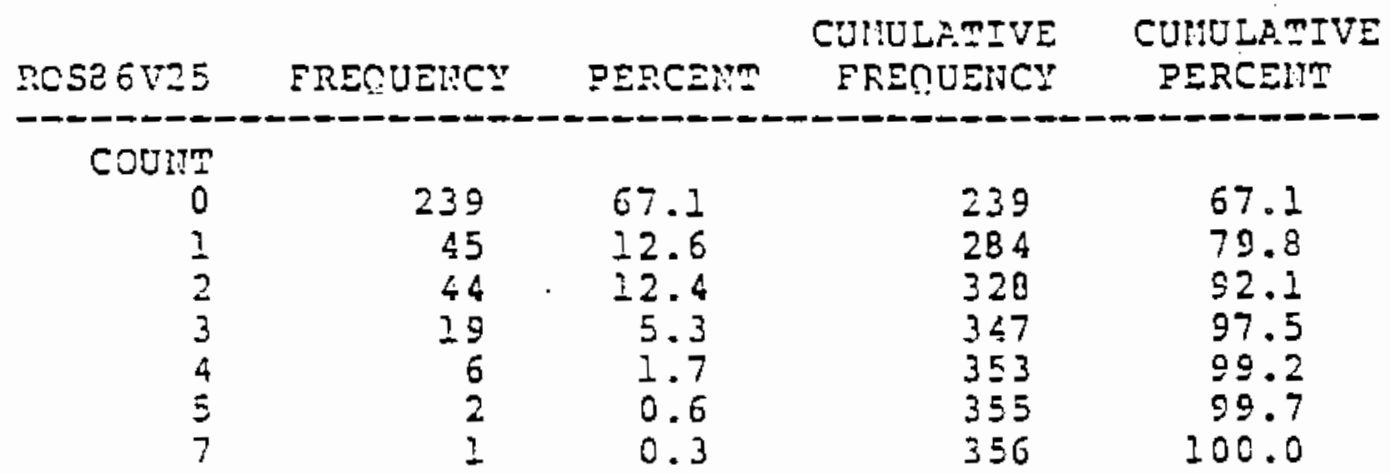


SAS

Ros86 sTATISTICS: pULsmion $+7 \mathrm{C}$

IOI HAIY PEOPLE LIVE IH YOU! HOUSELOLD, 10 MHRU 65 YEAPS OLD,

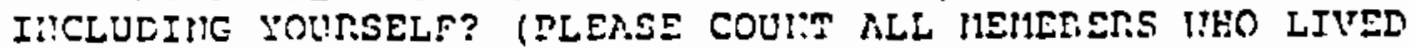
IH YOUR HOUSEHOLD FOR R.T LENS? C OF TIE PAS" 12 "MONT!S IHETIER OR MCT THEY ARE RELATED TO YOU.)

\begin{tabular}{|c|c|c|c|c|}
\hline 1.0586126 & ERENUENCY & PERCEHT & $\begin{array}{l}\text { CUIIUIAIIVE } \\
\text { ERINUEIICY }\end{array}$ & $\begin{array}{l}\text { CUIULATIVE } \\
\text { PERCEHI }\end{array}$ \\
\hline $\begin{array}{r}\text { cours } \\
0 \\
1 \\
2 \\
3 \\
4\end{array}$ & $\begin{array}{r}49 \\
31 \\
223 \\
43 \\
10\end{array}$ & $\begin{array}{r}13.8 \\
8.7 \\
62.6 \\
12.1 \\
2.8\end{array}$ & $\begin{array}{r}49 \\
80 \\
303 \\
346 \\
356\end{array}$ & $\begin{array}{r}13.8 \\
22.5 \\
0.5 \\
97.2 \\
100.0\end{array}$ \\
\hline
\end{tabular}

D.0S06 ETATISTICS: NUESTION $\# 70$

WOM : IHCLUDIIU YOUTSELE? (PLEASE COUHT ALL IIEHEEERS MHO LIVEN I1: YOUR HOUSEHOLD FOR AT LEAST 6 OF THE PAST 12 MONTIS MEETHER OR HOT THEY ARE RELP.TED TO YOU.।

\begin{tabular}{rrrrr} 
ROSSU127 & EREOUENCY & PERCENT & $\begin{array}{c}\text { CUMULATIVE } \\
\text { ERENULNCY }\end{array}$ & $\begin{array}{c}\text { CUHULATTYE } \\
\text { PERCENI }\end{array}$ \\
\hline COUIT & & & & \\
0 & 295 & 62.9 & 295 & 82.9 \\
1 & 27 & 7.6 & 322 & 50.4 \\
2 & 34 & 8.6 & 356 & 100.0
\end{tabular}

ROSG SMATEMICS: QUESTIOH LOA

THIT:T IS YOUR AEE?

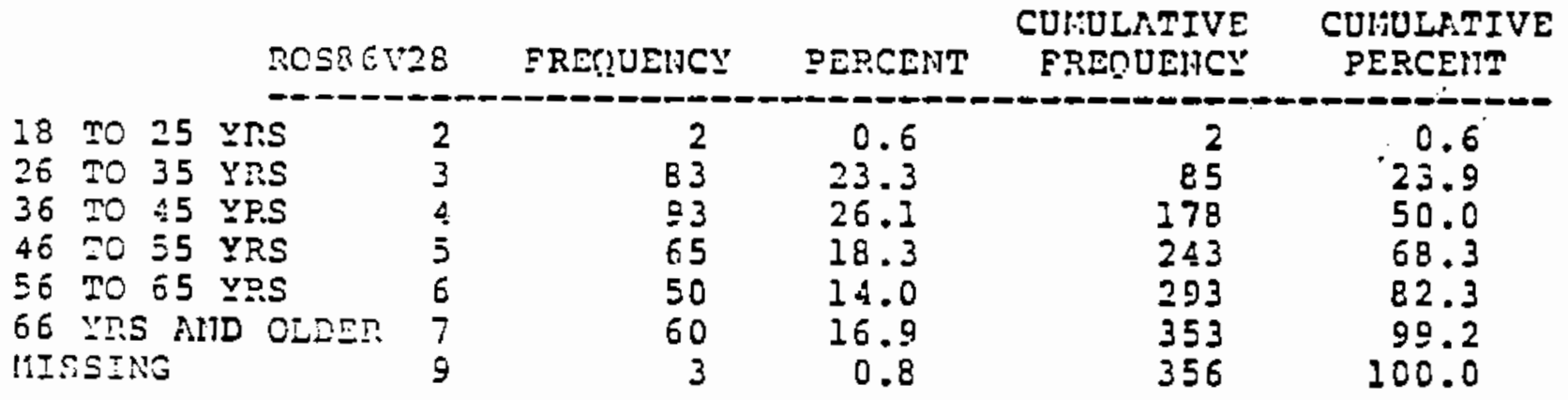


SAS

ROS86 STATISmICS: NUESFIOH $\# 8 B$

WHAT IS THE AGE OF THE SECOID HOUSEHOLDER?

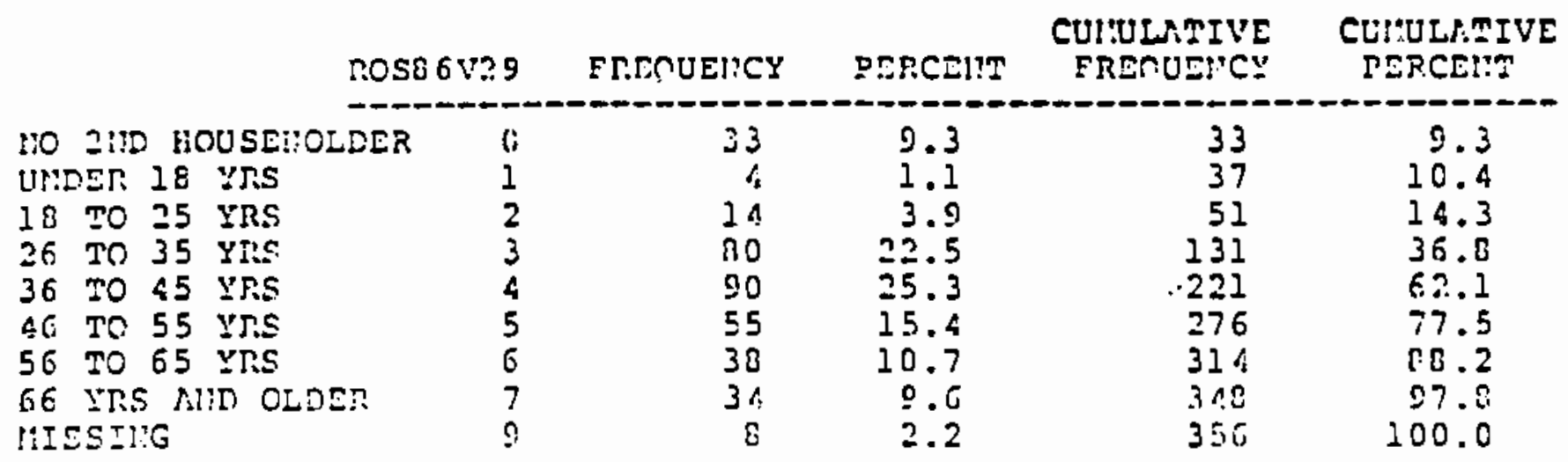

ROSB 6 STATISTICS: NUESTION

WHAT IS YOUR SER?

\begin{tabular}{|c|c|c|c|c|c|}
\hline & Rose 6030 & EREOUENCY & PERCE!T & $\begin{array}{l}\text { CUIUULATIVE } \\
\text { ERENUENCY }\end{array}$ & $\begin{array}{l}\text { CUIULATIVE } \\
\text { PERCEITT }\end{array}$ \\
\hline $\begin{array}{l}\text { HALE } \\
\text { EE!MALE } \\
\text { IIISSIMG }\end{array}$ & $\begin{array}{l}1 \\
2 \\
9\end{array}$ & $\begin{array}{r}252 \\
102 \\
2\end{array}$ & $\begin{array}{r}70.8 \\
28.7 \\
0.6\end{array}$ & $\begin{array}{l}252 \\
354 \\
356\end{array}$ & $\begin{array}{r}70.8 \\
29.4 \\
100.0\end{array}$ \\
\hline
\end{tabular}

ROS86 STATISTICS: QUESTION \&OE

WHAT IS TRE SE: OF THE SECOND HOUEEHOLDER?

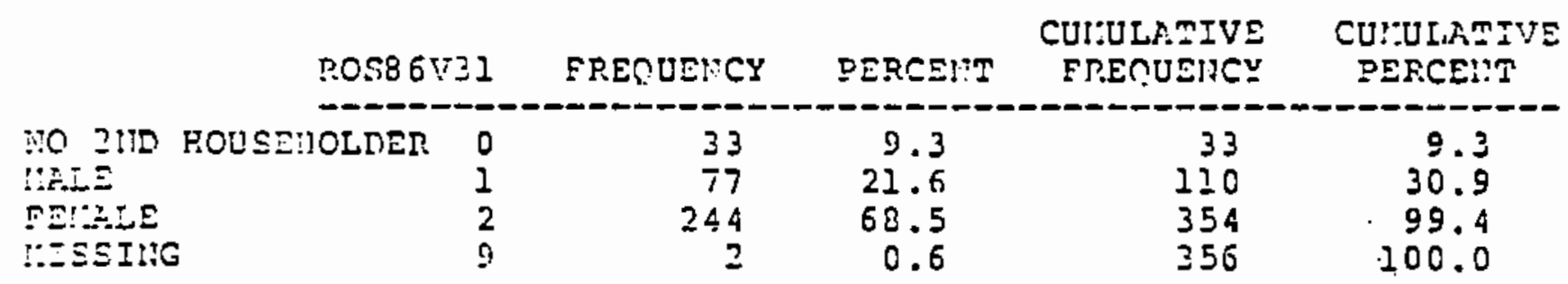

ROSE STATISTICS: RUESTION \#10A

ARE YOU EHPLOYED FULL-TIHE?

\begin{tabular}{|c|c|c|c|c|c|}
\hline & P.050 $6 \times 32$ & FRENUENCY & DERCEIT & $\begin{array}{l}\text { CURULATIVE } \\
\text { FREOUEICY }\end{array}$ & $\begin{array}{l}\text { CUMLLATIVE } \\
\text { PERCEMT }\end{array}$ \\
\hline $\begin{array}{l}: 0 \\
\because E S \\
y E S I M G\end{array}$ & $\begin{array}{l}0 \\
1 \\
9\end{array}$ & $\begin{array}{r}130 \\
224 \\
2\end{array}$ & $\begin{array}{r}36.5 \\
62.9 \\
0.6\end{array}$ & $\begin{array}{l}130 \\
354 \\
356\end{array}$ & $\begin{array}{r}36.5 \\
99.4 \\
100.0\end{array}$ \\
\hline
\end{tabular}


SAS

ROSB 6 SSATISICS: NUESTION! \&LD

IS TIE SECOHD HOUSEMOLNER EHIPLOYLD FULL-TI:IE?

\begin{tabular}{|c|c|c|c|c|c|c|}
\hline & $\operatorname{sos} 6 \mathrm{~V}$ & 33 & FRECUEICY & PERCEIT & $\begin{array}{l}\text { CUIULA.TIVE } \\
\text { FRECUE:?CV }\end{array}$ & $\begin{array}{l}\text { CUIIULATIVE } \\
\text { PERCEITI }\end{array}$ \\
\hline 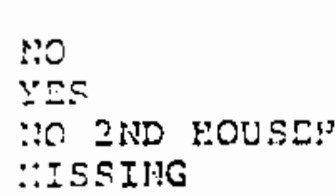 & OLDER & $\begin{array}{l}0 \\
1 \\
2 \\
9\end{array}$ & $\begin{array}{r}175 \\
143 \\
33 \\
5\end{array}$ & $\begin{array}{l}4.2 .2 \\
40.2 \\
9.3 \\
1.4\end{array}$ & $\begin{array}{l}175 \\
318 \\
351 \\
356\end{array}$ & $\begin{array}{r}48 \cdot 2 \\
89.3 \\
98.6 \\
100.0\end{array}$ \\
\hline
\end{tabular}

F.0586 STATISTICS: กUESTION HIIA

WHR. IS THE LIST GTADE OR YER OF SCHNCL COMPLTED BY YOURSELF?

\begin{tabular}{|c|c|c|c|c|c|}
\hline $20586 \mathrm{~V}$ & & EREOQUENCY & PERCENT & $\begin{array}{l}\text { CUI:ULATIVE } \\
\text { FREOUENCY }\end{array}$ & $\begin{array}{l}\text { CUIULATIVE } \\
\text { PERCEHT }\end{array}$ \\
\hline 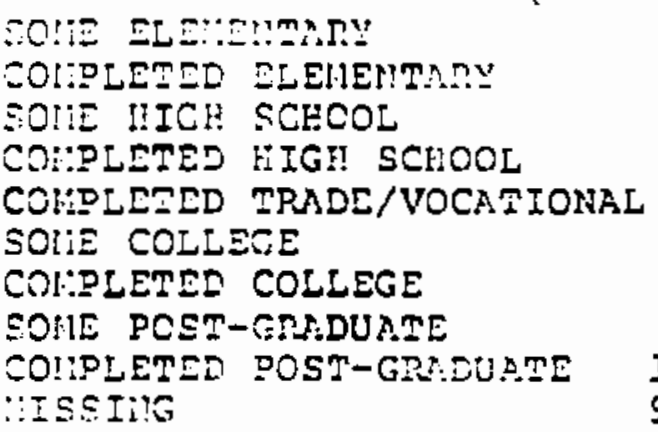 & $\begin{array}{r}2 \\
3 \\
4 \\
5 \\
6 \\
7 \\
8 \\
9 \\
10 \\
50\end{array}$ & $\begin{array}{r}1 \\
12 \\
15 \\
52 \\
32 \\
95 \\
66 \\
25 \\
50 \\
8\end{array}$ & $\begin{array}{r}0.3 \\
3.4 \\
4.2 \\
24.6 \\
9.0 \\
26.7 \\
18.5 \\
7.0 \\
14.0 \\
2.2\end{array}$ & $\begin{array}{r}11 \\
23 \\
28 \\
80 \\
112 \\
207 \\
273 \\
298 \\
348 \\
350\end{array}$ & $\begin{array}{r}0.3 \\
3.7 \\
7.9 \\
22.5 \\
31.5 \\
58.1 \\
76.7 \\
8.7 \\
97.8 \\
100.0\end{array}$ \\
\hline
\end{tabular}

$$
\begin{aligned}
& \text { ROS8 } 6 \text { STATISTICS: CUESTIOH AII } \\
& \text { WUAM IS TEE LAST GRUE OR YEAR OF SCHOOL COIPLETED RY THE SECOH: }
\end{aligned}
$$

:20 2YD LOUSEHCLDER

SOUE ELE::E?:TARY

CORTLLEED ELEMEMMARY

SO:A RIGL SCHOOI,

COIYDLETED HIGH SCHOOL

COIZLEPED TREDE/VOCATIOIIAJ

SOHE COLLEGL

COKPLIEET COLLEGE

SOHE POST-GRADUATE

COLPLETED POST-GRADURE 10

IISEI!G

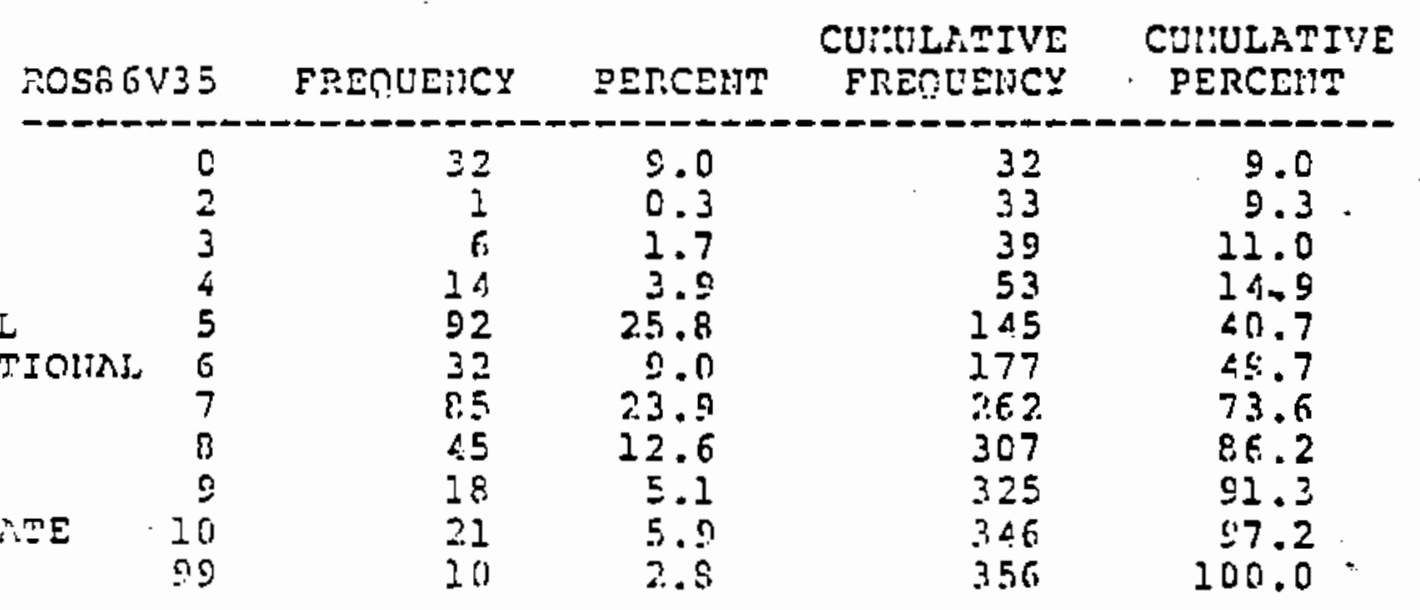


sns

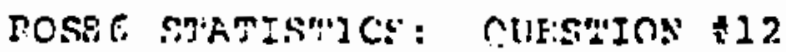

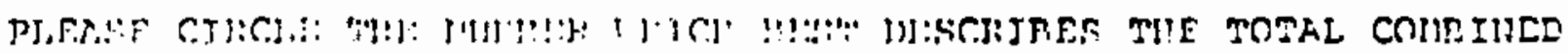

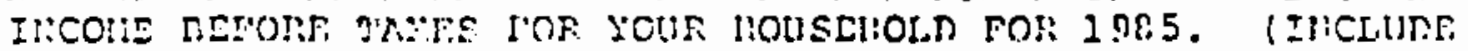

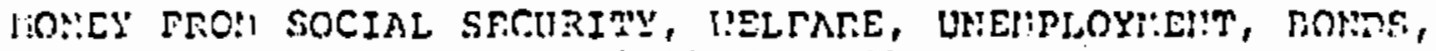

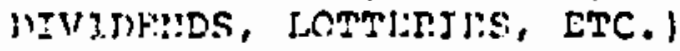

\begin{tabular}{|c|c|c|c|c|c|}
\hline & & FFEDUIASY & PERCEIT & $\begin{array}{l}\text { CUIULATIVE: } \\
\text { FREOUEHCY }\end{array}$ & $\begin{array}{l}\text { GIHULJTIVT } \\
\text { PERCEHT }\end{array}$ \\
\hline 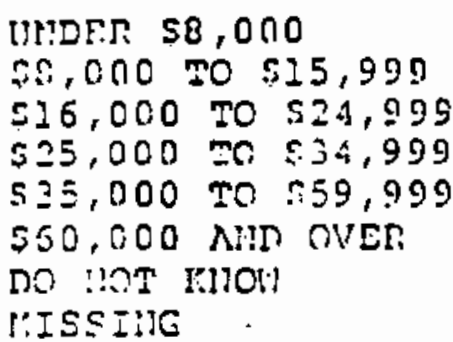 & $\begin{array}{l}1 \\
2 \\
3 \\
4 \\
5 \\
6 \\
8 \\
9\end{array}$ & $\begin{array}{r}13 \\
38 \\
61 \\
83 \\
102 \\
30 \\
7 \\
22\end{array}$ & $\begin{array}{r}3.7 \\
10.7 \\
17.1 \\
23.3 \\
28.7 \\
8.4 \\
2.0 \\
6.2\end{array}$ & $\begin{array}{r}13 \\
51 \\
112 \\
195 \\
297 \\
327 \\
334 \\
356\end{array}$ & $\begin{array}{r}3.7 \\
14.3 \\
31.5 \\
54.8 \\
03.4 \\
91.9 \\
93.8 \\
100.0\end{array}$ \\
\hline
\end{tabular}


SP.S

ROSB 6 STAMISTICS: QUCSTION 13 A

PLEASE ESTIUTE ITHAT PEECENM OF YOUR TOTAL COIIIIUEN INCOIE FOR lEQ5 URS BLLOCR.TED TO TRAHSPORTATION (CAR/LEASE PAYHELTS).

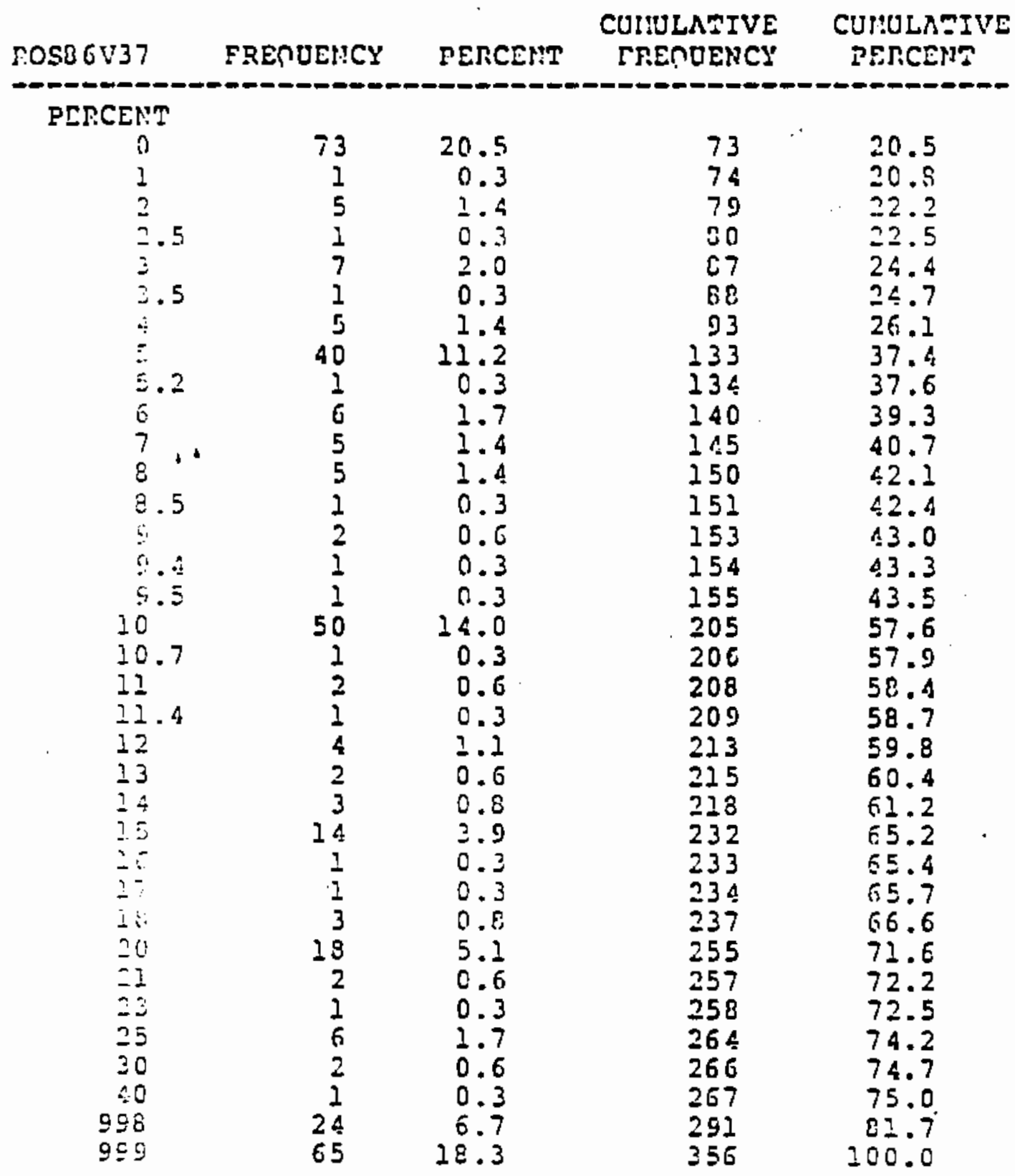


SAS

ROSB , STATISTICS: NUESTIOM $\# 130$

PLENSE ESTI!MTE VHAT RERCEM OF YOUR TOTAL COMDIIED IMCOME FOR 2985 TAS ALLOCRTED TO YOUSIIG (HORTGAGE, TEEIT).

\begin{tabular}{|c|c|c|c|c|}
\hline nosa 6У3R & ГRERUCHCY & PERCEIT & $\begin{array}{l}\text { CUIULATIVE } \\
\text { FRENUEHCY }\end{array}$ & $\begin{array}{l}\text { CUITULATIVE } \\
\text { PERCEI:T }\end{array}$ \\
\hline PERCEIIT & & & & \\
\hline 0 & 35 & 9.8 & 35 & 9.8 \\
\hline 9 & 1 & 0.3 & 36 & 20.1 \\
\hline 2.5 & $j$ & 0.3 & 37 & $\because 10.4$ \\
\hline 3 & $i$ & 0.3 & 38 & 10.7 \\
\hline 5 & 4 & 1.1 & 42 & 11.8 \\
\hline 6 & 3 & 0.8 & 45 & 12.6 \\
\hline 7 & 2 & 0.6 & 47 & 13.2 \\
\hline 8 & 4 & 1.1 & 51 & 14.3 \\
\hline 10 & 19 & 5.3 & 70 & 10.7 \\
\hline 11 & 3 & 0.8 & 73 & 20.5 \\
\hline 12 & 5 & 1.4 & 78 & 21.9 \\
\hline 13 & 1 & 0.3 & 79 & 22.2 \\
\hline 14 & 1 & 0.3 & BO & 22.5 \\
\hline 15 & 20 & 5.6 & 100 & 28.1 \\
\hline 16 & 3 & 0.8 & 103 & 28.9 \\
\hline 17 & 3 & 0.8 & 106 & 20.8 \\
\hline 18 & 8 & 2.2 & 114 & 32.0 \\
\hline 15 & 2 & 0.6 & 116 & 32.6 \\
\hline 20 & 29 & 8.1 & $1 \leqslant 5$ & 40.7 \\
\hline 21 & 4 & 1.1 & 119 & 41.9 \\
\hline 22 & 1 & 0.3 & 150 & 42.1 \\
\hline 23 & 1 & 0.3 & 151 & 42.4 \\
\hline 23.1 & 2 & 0.3 & 152 & 42.7 \\
\hline 23.6 & 1 & 0.3 & 153 & 43.0 \\
\hline $2 A$ & 3 & 0.8 & 156 & 43.8 \\
\hline $2 \equiv$ & 31 & 0.7 & 167 & 52.5 \\
\hline$? 6.5$ & 1 & 0.3 & 188 & 52.8 \\
\hline 27 & 2 & 0.6 & $1 \subseteq 0$ & 53.4 \\
\hline$=7.5$ & 1 & 0.3 & 19 & 53.7 \\
\hline 26 & 2 & 0.6 & 103 & 54.2 \\
\hline 30 & 27 & 7.6 & 220 & 61.8 \\
\hline 31 & 1 & 0.3 & 221 & 62.1 \\
\hline 32 & 1 & 0.3 & 222 & 62.4. \\
\hline 33 & 11 & 3.1 & 233 & 65.4 \\
\hline 35 & 11 & 3.1 & 244 & 68.5 \\
\hline 38 & 1 & 0.3 & 245 & 68.8 \\
\hline 28.3 & 1 & 0.3 & 246 & 69.1 \\
\hline$\div 0$ & 11 & 3.1 & 257 & 72.2 \\
\hline 45 & 2 & 0.6 & 259 & 72.8 \\
\hline$\Delta E$ & 1 & 0.3 & 260 & 73.0 \\
\hline 50 & 5 & 1.4 & $2 \in 5$ & 74.4 \\
\hline EO & 1 & 0.3 & 266 & 74.7 \\
\hline 75 & 1 & 0.3 & 267 & 75.0 \\
\hline 998 & 24 & 6.7 & 291 & 8.7 \\
\hline 999 & 55 & 18.3 & 356 & 100.0 \\
\hline
\end{tabular}




\section{$5 \lambda 5$}

ROSE STAmIS:ICS: NUESTIO! Al3C

DLENSE ENAIMRE ITAT PERCEIT OF YOLR GOTAL COIBIHED IFCOHE FOR 2985 ras iLLOCATSD TO HOUSEHOLD DURABLES (FURIITURE, SMOVE, insNER.S, CTC.).

\begin{tabular}{|c|c|c|c|c|}
\hline rose $6: 39$ & ERENUE!CY & RERCEIT & $\begin{array}{l}\text { CHHULAPIVE } \\
\text { FREQUE:ICY }\end{array}$ & $\begin{array}{l}\text { CUI:ULATIVE } \\
\text { PERCEI: }\end{array}$ \\
\hline 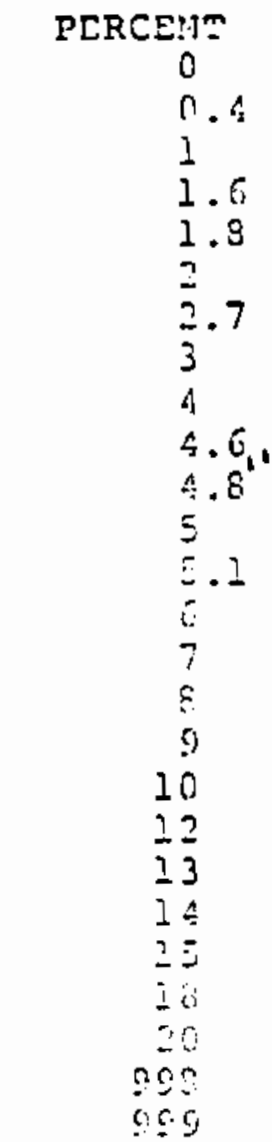 & $\begin{array}{r}85 \\
1 \\
18 \\
1 \\
1 \\
28 \\
1 \\
14 \\
5 \\
1 \\
1 \\
46 \\
1 \\
7 \\
4 \\
4 \\
1 \\
36 \\
2 \\
1 \\
1 \\
5 \\
1 \\
2 \\
24 \\
65\end{array}$ & $\begin{array}{r}23.9 \\
0.3 \\
5.1 \\
0.3 \\
0.3 \\
7.9 \\
0.3 \\
3.9 \\
1.4 \\
0.3 \\
0.3 \\
12.9 \\
0.3 \\
2.0 \\
1.1 \\
1.1 \\
0.3 \\
10.1 \\
0.6 \\
0.3 \\
0.3 \\
1.3 \\
0.3 \\
0.6 \\
E .7 \\
18.3\end{array}$ & $\begin{array}{l}85 \\
86 \\
104 \\
105 \\
106 \\
134 \\
135 \\
149 \\
154 \\
155 \\
156 \\
202 \\
203 \\
210 \\
214 \\
216 \\
219 \\
255 \\
257 \\
258 \\
259 \\
264 \\
265 \\
267 \\
291 \\
356\end{array}$ & $\begin{array}{r}23.9 \\
24.2 \\
29.2 \\
29.5 \\
29.8 \\
37.6 \\
37.9 \\
41.9 \\
43.3 \\
43.5 \\
43.8 \\
56.7 \\
57.0 \\
59.0 \\
60.1 \\
61.2 \\
61.5 \\
71.6 \\
72.2 \\
72.5 \\
72.8 \\
74.2 \\
74.4 \\
75.0 \\
81.7 \\
100.0\end{array}$ \\
\hline
\end{tabular}


SAS

ROSB6 STATIETICS: NUESTION 4230

PLEASE ESTIMATE THAT DERCEMT OF YOUR. TOTAL COHAIMED INCOIE FOR 2985 TISS A.LLOCAZED TO HOUSEHOLD EMRRGY (ELECTRICITY, AUTOIORILE GNS/OIL).

\begin{tabular}{|c|c|c|c|c|}
\hline RosB CVAO & FREOUEHCY & PEICEITT & $\begin{array}{l}\text { CUHULATIVE } \\
\text { FRENUEYCY }\end{array}$ & $\begin{array}{c}\text { CUIULATIVE } \\
\text { PERCEIT }\end{array}$ \\
\hline 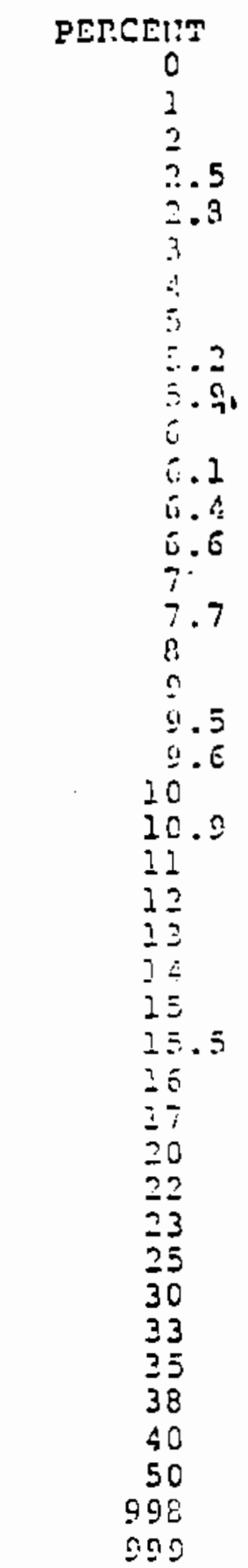 & $\begin{array}{r}6 \\
1 \\
4 \\
2 \\
1 \\
0 \\
9 \\
31 \\
1 \\
1 \\
10 \\
1 \\
1 \\
1 \\
6 \\
1 \\
10 \\
10 \\
2 \\
1 \\
61 \\
1 \\
1 \\
8 \\
3 \\
2 \\
30 \\
1 \\
1 \\
1 \\
30 \\
1 \\
1 \\
8 \\
6 \\
1 \\
1 \\
1 \\
3 \\
1 \\
24 \\
65\end{array}$ & $\begin{array}{l}1.7 \\
0.3 \\
1.1 \\
0.7 \\
0.3 \\
1.7 \\
2.3 \\
0.7 \\
0.3 \\
0.3 \\
2.8 \\
0.3 \\
0.3 \\
0.3 \\
1.7 \\
0.3 \\
2.3 \\
2.8 \\
0.3 \\
0.3 \\
17.1 \\
0.3 \\
0.3\end{array}$ & $\begin{array}{l}6 \\
7 \\
11 \\
13 \\
14 \\
20 \\
29 \\
60 \\
61 \\
62 \\
72 \\
73 \\
74 \\
75 \\
81 \\
112 \\
92 \\
102 \\
104 \\
105 \\
166 \\
167 \\
168 \\
176 \\
179 \\
181 \\
211 \\
212 \\
213 \\
214 \\
244 \\
245 \\
246 \\
254 \\
260 \\
261 \\
262 \\
263 \\
266 \\
267 \\
281 \\
356\end{array}$ & $\begin{array}{r}1.7 \\
2.0 \\
3.1 \\
3.7 \\
3.9 \\
5.6 \\
8.1 \\
16.0 \\
17.1 \\
17.4 \\
20.2 \\
20.5 \\
20.8 \\
21.1 \\
22.8 \\
23.0 \\
25.8 \\
28.7 \\
29.2 \\
29.5 \\
46.6 \\
46.9 \\
47.2 \\
49.4 \\
50.3 \\
50.8 \\
59.3 \\
59.6 \\
59.8 \\
60.1 \\
68.5 \\
68.8 \\
69.1 \\
71.3 \\
73.0 \\
73.3 \\
73.6 \\
73.9 \\
74.7 \\
75.0 \\
81.7 \\
100.0\end{array}$ \\
\hline
\end{tabular}




\section{SAS}

ROSE 6 STATISmICS: rUESTION

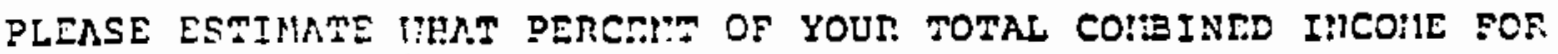
1085 MI.S MLLOCNTEI TO FOON.

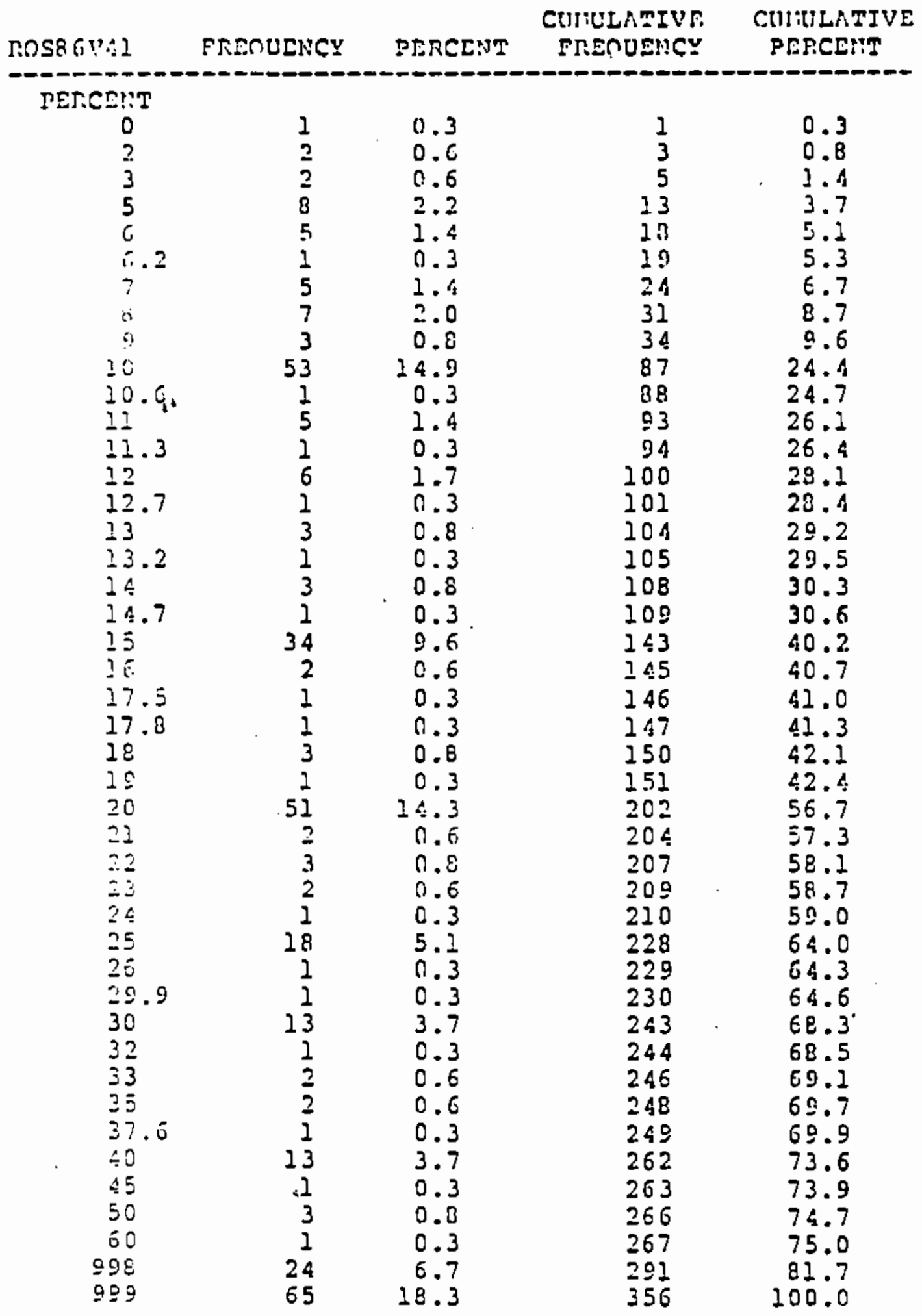


SnS

ROSS6 STATASTCS: nUESTIOH $413 \mathrm{I}$

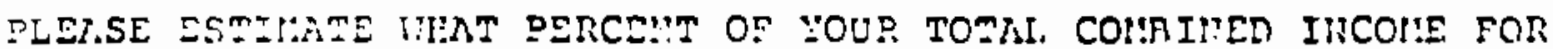
1985 ths NLLOCNTED mo CLOTHIJU.

\begin{tabular}{|c|c|c|c|c|}
\hline POSSOVA 2 & EREOUENCY & PERCENT & $\begin{array}{l}\text { CUISTLATIVE } \\
\text { EREOUEUCY }\end{array}$ & $\begin{array}{l}\text { CUIULATIVE } \\
\text { DERCEYT }\end{array}$ \\
\hline PERCS!? & & & 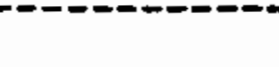 & \\
\hline 0 & 13 & 3.7 & 13 & 3.7 \\
\hline 0.5 & 1 & 0.3 & 14 & 2.9 \\
\hline 6.9 & 1 & 0.3 & 25 & $c_{2} .2$ \\
\hline$i$ & 6 & 1.7 & 21 & 5.9 \\
\hline 2.5 & 1 & 0.3 & 22 & 0.2 \\
\hline 3.0 & 1 & 0.3 & 23 & 6.5 \\
\hline 2 & 32 & 0.0 & 55 & 15.4 \\
\hline 2.4 & 2 & 0.3 & 56 & 15.7 \\
\hline 2.5 & 2 & 0.6 & 58 & 16.3 \\
\hline 2.0 & $i$ & 0.3 & 59 & 16.6 \\
\hline 314 & 20 & 2.8 & 60 & 19.4 \\
\hline 2.5 & 1 & 0.3 & 70 & 19.7 \\
\hline 4 & 14 & 3.9 & 84 & 23.6 \\
\hline$A .8$ & $i$ & 0.3 & 85 & 23.9 \\
\hline$\rightarrow .9$ & $\overline{1}$ & 0.3 & 06 & 24.2 \\
\hline $\bar{\Sigma}$ & 73 & 20.5 & 150 & 44.7 \\
\hline 8 & 8 & 2.2 & 167 & 46.9 \\
\hline 7 & 7 & 2.0 & 174 & 42.9 \\
\hline 7.5 & 1 & 0.3 & 175 & 49.2 \\
\hline$a$ & 8 & 2.2 & 183 & 51.4 \\
\hline 10 & 63 & 27.7 & 246 & 69.1 \\
\hline 11 & 2 & 0.6 & 248 & 69.7 \\
\hline$I \div$ & 1 & 0.3 & 249 & 69.9 \\
\hline$\Xi$ & 11 & 3.1 & 260 & 73.0 \\
\hline$\because$ & 1 & 0.3 & 261 & 73.3 \\
\hline$\therefore 0$ & 5 & 3.4 & 266 & 74.7 \\
\hline 20 & $I$ & 0.3 & 267 & 75.0 \\
\hline 95 & 24 & 6.7 & 291 & 81.7 \\
\hline 299 & 65 & 18.3 & 356 & 100.0 \\
\hline
\end{tabular}


SAS

R.OS86 STATISMICS: CUESTIOH $113 \mathrm{~F}$

PLENSE ESTIIAEE ITHAT PERCEIAT OF YOUR TOMAL COHFINEN INCOIIL FOR 1985 INS ALLOCR.TED TO RECREAMION/EYTERTAINIEHT (FISHIHG, BORLING, I:OVIES, ECT.).

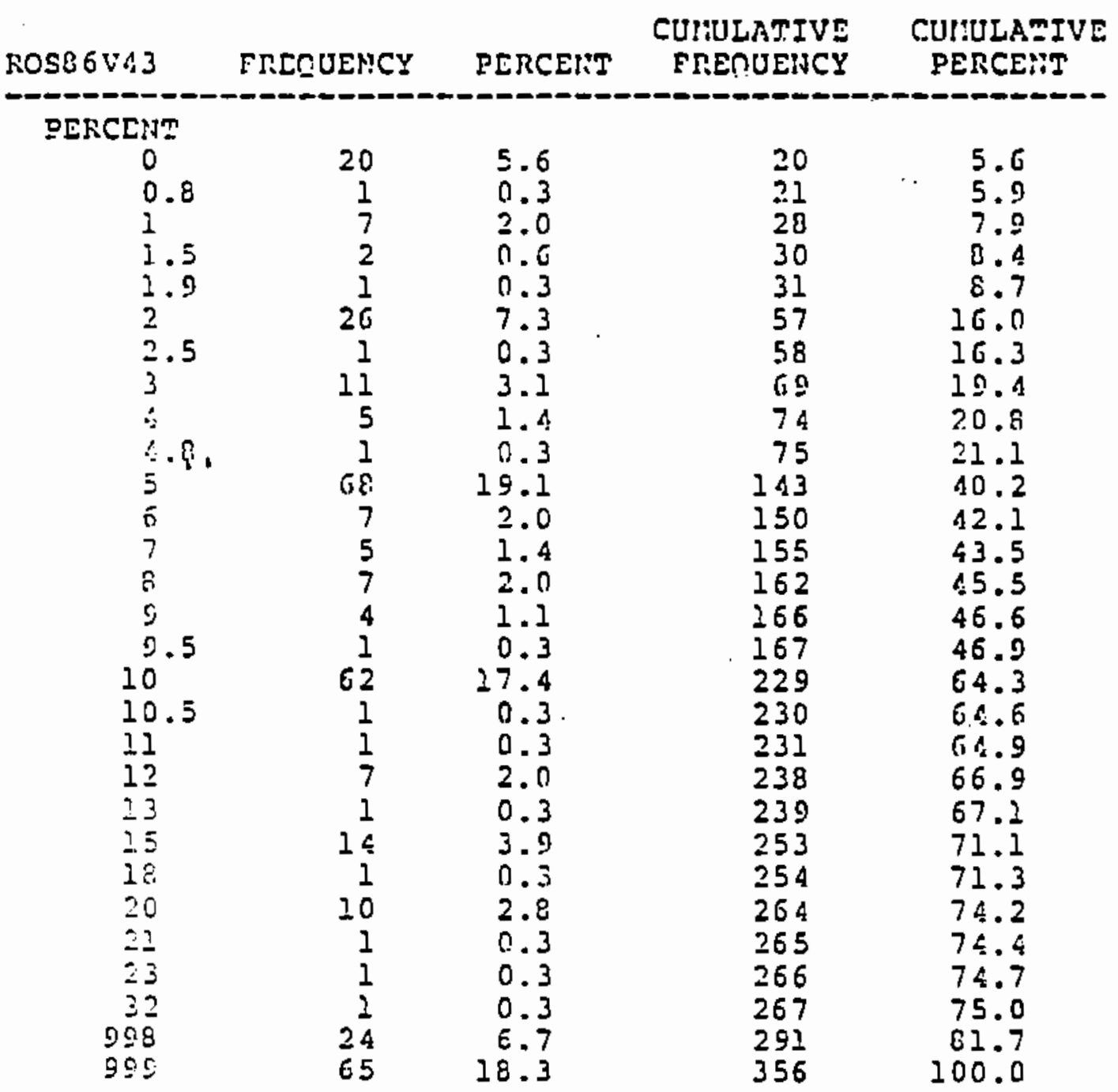


SAS.

ROSB 6 STATISTICS: OUESTION $\# 13 G$

DLEAST ESTIHATE IHAT DERCEIT OF YOUR TOMAL COMBIHEN INCOHE FOR 1.985 WAS MLLOCITED TO HEDICAL.

\begin{tabular}{|c|c|c|c|c|}
\hline $\operatorname{nos} 6 \mathrm{~V} i \mathrm{~A}$ & FISERUEICY & PERCEIT & $\begin{array}{l}\text { CUIULATIVE } \\
\text { ERECUEHCY }\end{array}$ & $\begin{array}{l}\text { CURULATIV } \\
\text { PERCEHT }\end{array}$ \\
\hline PERCEITT & & & & 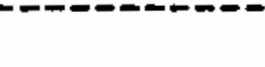 \\
\hline 0 & 41 & 11.5 & 41 & 11.5 \\
\hline 0.1 & 1 & 0.3 & 42 & 11.8 \\
\hline 1 & 20 & 5.6 & 62 & 17.4 \\
\hline 2 & 19 & 5.3 & 81 & 22.8 \\
\hline 2.2 & 1 & 0.3 & 82 & 23.0 \\
\hline 2.5 & $\overline{1}$ & 0.3 & 83 & 23.3 \\
\hline 3 & 18 & 5.1 & 101 & 28.4 \\
\hline$\vdots .1$ & 1 & 0.3 & 102 & 28.7 \\
\hline 2.5 & $\overline{1}$ & 0.3 & 103 & 28.9 \\
\hline$\therefore$ & 7 & 2.0 & 110 & 30.9 \\
\hline$\therefore 2$. & 1 & 0.3 & 111 & 31.2 \\
\hline 4.5 & I & 0.3 & 112 & 31.5 \\
\hline$=-6$ & 1 & 0.3 & 113 & 31.7 \\
\hline 5 & 62 & 17.4 & 175 & 49.2 \\
\hline 6 & 7 & 2.0 & 182 & 51.1 \\
\hline 7 & 3 & 0.8 & 185 & 52.0 \\
\hline 7.3 & 1 & 0.3 & 186 & 52.2 \\
\hline 8 & 9 & 2.5 & 195 & 54.8 \\
\hline 0.5 & 2 & 0.6 & 197 & 55.3 \\
\hline$c_{5}$ & 2 & 0.6 & 199 & 55.9 \\
\hline 10 & 45 & 12.6 & 244 & 68.5 \\
\hline 11 & 1 & 0.3 & 245 & 68.8 \\
\hline 22.5 & 1 & 0.3 & 246 & 69.1 \\
\hline 15 & 8 & 2.2 & 254 & 71.3 \\
\hline 18 & 1 & 0.3 & 255 & 71.6 \\
\hline 20 & 6 & 1.7 & 261 & 73.3 \\
\hline 23.0 & 1 & 0.3 & 2.62 & \\
\hline 25 & 4 & 1.1 & 266 & 76.7 \\
\hline 32 & 1 & 0.3 & 267 & 75.0 \\
\hline S56 & 24 & E. 7 & 29 & \\
\hline 095 & 65 & 18.3 & 356 & 100.0 \\
\hline
\end{tabular}


SA.S

ROSB6 STAFISTICS: QUESTION

PLENSE ESTIMATE THAT PERCEMT OF YOUR TOTAL COMIMIMED IMCO:LE FOR 1985 ITAS ALLOCATED TO SAVIUGS.

\begin{tabular}{|c|c|c|c|c|}
\hline R0506V 45 & FREOUEHCY & PERCEIPT & $\begin{array}{l}\text { CU!ULATIVE } \\
\text { FREOUEICY }\end{array}$ & $\begin{array}{l}\text { CURULATIVE } \\
\text { PERCENT }\end{array}$ \\
\hline DERCET & & & & \\
\hline 0 & 64 & 18.0 & 68 & $1 E .0$ \\
\hline 0.2 & 1 & 0.3 & 65 & 18.3 \\
\hline 2 & 10 & 2.8 & 75 & 21.1 \\
\hline 2 & 7 & 2.0 & 12 & 23.0 \\
\hline 2.8 & $i$ & 0.3 & 03 & 23.3 \\
\hline 3 & $\dot{9}$ & 2.5 & 92 & 25.8 \\
\hline$\approx$ & $\epsilon$ & 1.7 & 98 & 27.5 \\
\hline 5.3 & 1 & 0.3 & 99 & 27.8 \\
\hline 4.5 & $i$ & 0.3 & 100 & 28.1 \\
\hline 5 & 34 & 0.6 & 134 & 37.6 \\
\hline 6 & 3 & 0.8 & 137 & 38.5 \\
\hline 7 & 3 & 0.8 & 140 & 39.3 \\
\hline$\tilde{a}$ & 4 & 1.1 & 144 & 10.4 \\
\hline 6.8 & 1 & 0.3 & 105 & 40.7 \\
\hline 9 & 2 & 0.6 & 147 & 41.3 \\
\hline 10 & 45 & 12.6 & 102 & 53.9 \\
\hline 21 & 2 & 0.6 & 194 & 54.5 \\
\hline 11.7 & 1 & 0.3 & 185 & 54.8 \\
\hline 12 & 5 & 1.4 & 200 & 56.2 \\
\hline 13 & 2 & 0.6 & 202 & 56.7 \\
\hline 14 & 1 & 0.3 & 203 & 57.0 \\
\hline 15 & 11 & 2.1 & 214 & 60.1 \\
\hline 16 & 3 & 0.3 & 217 & 61.0 \\
\hline 18 & 1 & 0.3 & 228 & 61.2 \\
\hline 15 & 2 & 0.6 & 220 & 61.3 \\
\hline 20 & 13 & 3.7 & 233 & 65.4 \\
\hline 21 & $i$ & 0.3 & 2.34 & 65.7 \\
\hline 23.4 & 1 & C. 3 & 235 & $6 \pi .0$ \\
\hline 22 & $\overline{1}$ & 0.3 & 236 & 56.3 \\
\hline 22.2 & 2 & 0.6 & 2.38 & 66.9 \\
\hline 23.5 & 1 & 0.3 & 239 & 67.1 \\
\hline 25 & $\overline{1}$ & 0.3 & 240 & 67.4 \\
\hline 25 & 10 & 2.8 & 250 & 70.2 \\
\hline 28 & 1 & 0.3 & 251 & 70.5 \\
\hline 30 & 8 & 2.2 & 259 & 72.8 \\
\hline 35 & 2 & 0.6 & 261 & 73.3 \\
\hline 37 & $i$ & 0.3 & 262 & 73.6 \\
\hline 40 & 2 & 0.6 & 264 & 74.2 \\
\hline 41 & 1 & 0.3 & 265 & 76.4 \\
\hline 42 & 1 & 0.3 & 266 & 74.7 \\
\hline 55 & 1 & 0.3 & 267 & 75.0 \\
\hline 998 & 24 & 6.7 & 251 & 81.7 \\
\hline S90 & 65 & 16.3 & .356 & 300.0 \\
\hline
\end{tabular}


52.5

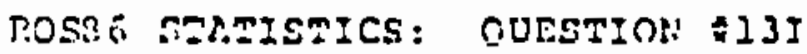

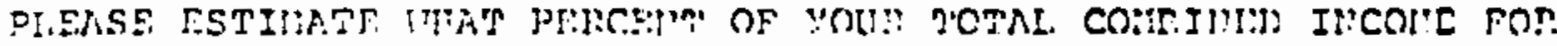
1985 las ALLOCLERD TO OTIER.

\begin{tabular}{|c|c|c|c|c|c|}
\hline SOSB GViF & 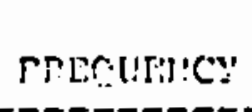 & percos:n' & $\begin{array}{l}\text { CUITULAEIVE: } \\
\text { TRETUEICY }\end{array}$ & $\begin{array}{l}\text { CHIULATIVE. } \\
\text { PERCENT }\end{array}$ & \\
\hline FERCFILI & & & & & - \\
\hline 0 & 3.27 & 35.7 & 127 & 35.7 & \\
\hline$?$ & J & 11.3 & 120 & 36.0 & \\
\hline 2 & 1 & 0.3 & $12 !$ & 36.2 & $\cdot$ \\
\hline$\therefore$ & 3 & 0.3 & 130 & 36.5 & \\
\hline$=$ & 3 & 0.8 & 133 & .37 .4 & \\
\hline 5 & 12 & 3.4 & 1.5 & 40.7 & $\cdot$ \\
\hline 6 & J & 0.3 & 146 & 41.0 & \\
\hline 7 & 1 & 0.3 & 147 & 4.1 .3 & \\
\hline !! & 5 & ]. $c$ & 352 & 62.7 & \\
\hline ! & 3 & (i. 8 & 1.55 & 43.5 & \\
\hline 36 & 16 & 6.5 & .172 & ה? & \\
\hline II & J & $1: .3$ & $.1 \%$ & $C E . .3$ & \\
\hline 17 & bi & 9.4 & .177 & 6.9 & \\
\hline $3: 5$ & .1 & $l^{\prime} . .3$ & $7 \%$ & 50.0 & \\
\hline 33 & ] & 0.3 & 1.79 & 50.3 & \\
\hline $3 \div$ & J & 0.3 & 180 & 50.6 & \\
\hline 15 & 11 & 3.1 & 191 & 53.7 & \\
\hline j. $f$. & $\bar{\jmath}$ & 0.3 & 3. 42 & 53.9 & \\
\hline .77 .5 & $j$ & 11.3 & 39.3 & 52.2 & \\
\hline $18:$ & 3 & 6.8 & 69 & $\leq 5.1$ & \\
\hline 39 & J & 4.3 & 3. 7 & 55.3 & \\
\hline 34.1 & 3 & 0.3 & 198 & 55.6 & \\
\hline 20 & 17 & 4.8 & 215 & 60.4 & \\
\hline$?$ & ? & 0.8 & 217 & . 1.0 & \\
\hline$\because 1.6$ & 2 & 8.3 & 219 & 63.2 & \\
\hline$\because$ & 1 & $11 . \therefore$ & $\because 9 !$ & (?.5 & \\
\hline$\because \because$ & 4 & 9 & $2 \% 3$ & $\therefore i f$ & \\
\hline$\therefore \therefore$ & $\therefore$ & 10.8 & $\because \therefore 6$ & $6: 5$ & \\
\hline$\because \vdots$ & 3 & 11.8 & 325 & 6.4 .3 & \\
\hline$\because c$ & 8 & 11.8 & 7.32 & $(.5)$. & \\
\hline 27 & $?$ & 0.6 & $\therefore 34$ & 65.7 & \\
\hline 27.3 & $?$ & 0.3 & 7.35 & +6.11 & \\
\hline 2.8 & 3 & 0.8 & 7.36 & $r(1,5$ & \\
\hline 30 & 8 & $\therefore .2$ & $? 46$ & 6.1 & \\
\hline 29 & I & 0.3 & 267 & $6 \div .4$ & . \\
\hline$\because$ & $\%$ & 6.6 & 245 & 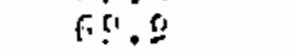 & \\
\hline$\because 2.5$ & 3 & 0.3 & 50 & 70.2 & \\
\hline 32.7 & 1 & 0.3 & 2.51 & 70.5 & \\
\hline 33 & . & 0.3 & \%.5\% & 910.8 & \\
\hline$\therefore 5$ & 1 & 0.3 & 253 & 73.2 & . \\
\hline$\therefore 6.2$ & i & 0.3 & 152 & i], 3 & \\
\hline 37 & 3 & 0.3 & 255 & 71.6 & \\
\hline $38:$ & 3 & 0.3 & $\% 56$ & 71.5 & . \\
\hline$=0.2$ & $?$ & 0.3 & 2.57 & 72.2 & \\
\hline$\angle 2$ & 2 & 0.6 & .259 & 72.8 & \\
\hline$\therefore 5$ & 3 & 0.3 & 360 & 73.0 & \\
\hline$C \therefore$ & 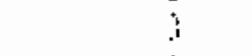 & $\because \ldots$ & 80 & $\because 3,3$ & \\
\hline$\because !$ & $\because$ & $\because 6$ & $: 8$ & 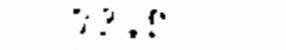 & \\
\hline$\therefore:^{\prime \prime}$ & $\because$ & 1,5 & $\because \vdots$ & $\because \therefore, A$ & \\
\hline
\end{tabular}




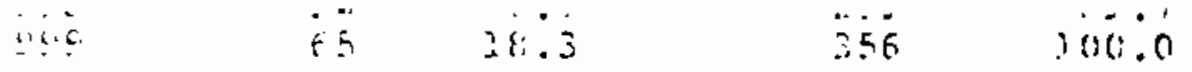

1 


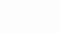

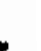


No. of

Copies

OFFSITE

Fred Abel

U.S. Department of Energy

Forrestal Building

Washington, D.C. 20585

30 DOE Technical Information

Center

ONSITE

DOE Richland Operations Office

J. J. Sutey

30 Pacific Northwest Laboratory

P. K. Alley

R. F. Darwin

D. L. Ivey (20)

P. W. Lewis

Publishing Coordination MH (2)

Technical Report Files (5) 


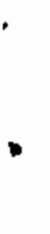

